Article

\title{
Relationship between oxygen species and activity/stability in heteroatom (Zr, Y)-doped cerium-based catalysts for catalytic decomposition of $\mathrm{CH}_{3} \mathrm{SH}$
}

\author{
Dingkai Chen a, Dehua Zhang a,*, Dedong He a,b, Jichang Lu a, Liping Zhong a, Caiyun Han a, \\ Yongming Luo a, \# \\ a Faculty of Environmental Science and Engineering, Kunming University of Science and Technology, Kunming 650500, Yunnan, China \\ ${ }^{\mathrm{b}}$ Faculty of Chemical Engineering, Kunming University of Science and Technology, Kunming 650500, Yunnan, China
}

\section{A R T I C L E I N F 0}

\section{Article history:}

Received 29 May 2018

Accepted 23 July 2018

Published 5 December 2018

\section{Keywords:}

Cerium-base catalyst

Heteroatom

Surface lattice oxygen

$\mathrm{CH}_{3} \mathrm{SH}$ decomposition

Bulk oxygen migration

\begin{abstract}
A B S T R A C T
$\mathrm{CeO}_{2}, \mathrm{Ce}_{1-x} \mathrm{Zr}_{x} \mathrm{O}_{2}$, and $\mathrm{Ce}_{1-x} \mathrm{Y}_{x} \mathrm{O}_{2-\delta}(x=0.25,0.50,0.75$, and 1.00$)$ have been rapidly synthesized to estimate their catalytic behavior in decomposing $\mathrm{CH}_{3} \mathrm{SH}$. The role of oxygen vacancies, and the relationship between the oxygen species and catalytic properties of $\mathrm{CeO}_{2}$ and $\mathrm{Zr}$-doped and Y-doped ceria-based materials are investigated in detail. Combining the observed catalytic performance with the characterization results, it can be deemed that surface lattice oxygen plays a critical role in methanethiol catalytic conversion over cerium oxides. $\mathrm{Ce}_{0.75} \mathrm{Zr}_{0.25} \mathrm{O}_{2}$ shows higher catalytic activity for $\mathrm{CH}_{3} \mathrm{SH}$ decomposition due to the large amount of surface lattice oxygen, readily available oxygen species, and excellent redox properties. $\mathrm{Ce}_{0.75} \mathrm{Y}_{0.25} \mathrm{O}_{2-\delta}$ displays better catalytic stability owing to the greater number of oxygen vacancies that would promote bulk lattice oxygen migration to the surface of the catalyst in order to replenish surface lattice oxygen. In addition, the results show that the difference in chemical valence between $\mathrm{Ce}$ and the heteroatoms would strongly influence the amount of surface lattice oxygen as well as the mobility of bulk-phase oxygen in these catalysts, thus affecting their activity and stability.
\end{abstract}

(C) 2018, Dalian Institute of Chemical Physics, Chinese Academy of Sciences. Published by Elsevier B.V. All rights reserved.

\section{Introduction}

Methanethiol, a volatile organic compound (VOC) existing in petroleum gas, natural gas etc., has been reported to cause serious human health and environmental problems when it is emitted into the atmosphere [1,2]. Therefore, the mercaptan content in these fossil fuels should be decreased to the lowest level (1-5 ppmv) [3] in the petroleum refining industry. Besides, $\mathrm{CH}_{3} \mathrm{SH}$ is unacceptable because it can lead to emissions of
$\mathrm{SO}_{x}$ and severe corrosion of metals, which is unfavorable for the transportation, storage, and use of these petroleum products [4-7]. Accordingly, eliminating $\mathrm{CH}_{3} \mathrm{SH}$ from natural gas and petroleum gas is urgently needed for the production of clean fossil fuels. Among all the methods for removing $\mathrm{CH}_{3} \mathrm{SH}$ [8-13], catalytic decomposition has been recognized as an efficient, economic, and ecological method; moreover, this method does not require additional reagents $\left(\mathrm{O}_{2}, \mathrm{H}_{2}\right.$, etc.), and it produces only a small amount of pollutants $[8,9]$.

\footnotetext{
* Corresponding author. Tel/Fax: +86-871-65103845; E-mail: environcatalysis222@yahoo.com \# Corresponding author. Tel/Fax: +86-871-65103845; E-mail: environcatalysis222@yahoo.com This work was supported by the National Natural Science Foundation of China (21667016, 21267011, U1402233). DOI: 10.1016/S1872-2067(18)63146-8 | http://www.sciencedirect.com/science/journal/18722067 | Chin. J. Catal., Vol. 39, No. 12, December 2018
} 
Cerium oxide or ceria, due to its prominent capability of oxygen storage/release, has been extensively applied to many catalytic reactions, including three-way catalytic converters (TWC) [14,15], hydrocarbon dry and steam reforming [16,17], fuel cell technology [18], low-temperature water gas shift $[19,20]$, and deep oxidation of VOCs [21-23]. The oxygen storage/release ability of ceria can be attributed to the cyclic switch between $\mathrm{Ce}^{4+}$ and $\mathrm{Ce}^{3+}$ oxidation states $\left(\mathrm{CeO}_{2} \leftrightarrow \mathrm{CeO}_{2-x}+1 / 2 x\right.$ $\left.\mathrm{O}_{2}\right)[24,25]$.

Of late, the application of ceria-based materials as catalysts to decompose $\mathrm{CH}_{3} \mathrm{SH}$ has also attracted much attention due to the production of simple and tractable inorganic products [26-31]. Laosiripojana and coworkers studied the decomposition behavior of $\mathrm{CH}_{3} \mathrm{SH}$ over a $\mathrm{CeO}_{2}$ catalyst for the first time and found that $\mathrm{CH}_{3} \mathrm{SH}$ could be completely decomposed to simple and tractable carbon products $\left(\mathrm{CH}_{4}, \mathrm{CO}\right.$, and $\left.\mathrm{CO}_{2}\right)$ and sulfur products $\left(\mathrm{H}_{2} \mathrm{~S}\right.$ etc.) [26]. However, the drawback of the catalyst was the high conversion temperature; the corresponding temperature for the complete catalytic conversion of $\mathrm{CH}_{3} \mathrm{SH}$ reached $800{ }^{\circ} \mathrm{C}$. In our previous study, it was found that $\mathrm{CH}_{3} \mathrm{SH}$ can be completely decomposed at $450{ }^{\circ} \mathrm{C}$ over $\mathrm{CeO}_{2}$ nanoparticles with a large surface area [28,29]. Unfortunately, nanoscale $\mathrm{CeO}_{2}$ catalysts are usually deactivated within $10 \mathrm{~h}$ in time-on-stream tests. A series of rare-earth $(\mathrm{RE}, \mathrm{RE}=\mathrm{Gd}, \mathrm{Nd}$, $\mathrm{Sm}$, etc.) modified cerium-based catalysts were developed to exhibit stability during the catalytic decomposition of $\mathrm{CH}_{3} \mathrm{SH}$, as compared to $\mathrm{CeO}_{2}$ [30,31]. The results indicate that the improved stability of the RE-doped catalysts is related to the formation of more oxygen vacancies; however, the role of oxygen vacancies in promoting catalytic stability has not been expounded. More importantly, the deactivation mechanism of $\mathrm{CH}_{3} \mathrm{SH}$ over ceria-based catalysts, and the interrelation between the oxygen species and catalytic behavior is not well understood. Therefore, it is necessary to further investigate the contribution of oxygen vacancies in improving the catalytic stability as well as reveal the relationship between the catalytic behavior and oxygen species.

In order to realize these objectives, we chose dopants with different valences (trivalent and tetravalent) and ionic radii as compared to Ce and studied the effects of valence and ionic radius of ceria dopants in the doped ceria-based catalysts on their activity and stability during $\mathrm{CH}_{3} \mathrm{SH}$ decomposition. We know that yttrium-doped ceria-based materials exhibit the best catalytic stability for $\mathrm{CH}_{3} \mathrm{SH}$ conversion among a series of trivalent ion (RE, $\mathrm{RE}=\mathrm{Y}^{3+}, \mathrm{Gd}^{3+}, \mathrm{Sm}^{3+}, \mathrm{La}^{3+}$, and $\mathrm{Nd}^{3+}$ )-doped ceria-based catalysts $[30,31]$. Moreover, the radius of the $\mathrm{Y}^{3+}$ ion $(1.03 \AA)$ is greater than that of the $\mathrm{Ce}^{4+}$ ion $(0.97 \AA)$. Therefore, the $\mathrm{Y}^{3+}$ ion was chosen as the trivalent dopant. Besides, it is widely accepted that the incorporation of $\mathrm{Zr}^{4+}$ increases the surface area, oxygen storage capability, and thermal stability, leading to outstanding catalytic ability [32-34]. As far as we know, there are no previous studies on $\mathrm{Zr}^{4+}$-doped cerium-based oxides for $\mathrm{CH}_{3} \mathrm{SH}$ conversion. Meanwhile, $\mathrm{Zr}^{4+}(0.84$ $\AA$ ) has a smaller ionic radius than does $\mathrm{Ce}^{4+}(0.97 \AA)$. Therefore, $\mathrm{Zr}$ was specifically chosen as the tetravalent dopant. Based on the above considerations, it can be deduced that $\mathrm{Zr}$ and $\mathrm{Y}$ ions are suitable for doping with ceria.
In this study, $\mathrm{CeO}_{2}$ and a series of heteroatom-doped Ce-based catalysts $\left(\mathrm{Ce}_{1-\mathrm{x}} \mathrm{Zr}_{x} \mathrm{O}_{2}\right.$ and $\mathrm{Ce}_{1-x} \mathrm{Y}_{x} \mathrm{O}_{2-\delta}, x=0.25,0.50$, 0.75 , and 1.00 ) were prepared by a citric acid complexation method with the aid of microwaves to research the impact of the valence and ionic radius on their catalytic activity and stability for $\mathrm{CH}_{3} \mathrm{SH}$ decomposition. The aim of this study is to investigate the role of oxygen vacancies, and the relationship between oxygen species and catalytic behavior via a series of characterization techniques. The aforesaid relationship can be classified into two categories: (1) relationship between surface lattice oxygen and catalytic activity and (2) relationship between bulk lattice oxygen migration and catalytic stability. Exploration of these two types of relationship will contribute to understanding the connection between the inherent properties of cerium-based materials and their catalytic behavior, and provide a fundamental basis for developing more efficient ceria-based catalysts.

\section{Experimental}

\subsection{Sample preparation}

The major procedures to rapidly prepare a series of $\mathrm{Ce}_{1-x} \mathrm{Zr}_{x} \mathrm{O}_{2}$ and $\mathrm{Ce}_{1-x} \mathrm{Y}_{x} \mathrm{O}_{2-\delta}(x=0.25,0.50$, and 0.75$)$ solid solutions and $\mathrm{CeO}_{2}, \mathrm{ZrO}_{2}$, and $\mathrm{Y}_{2} \mathrm{O}_{3}$ catalysts by a citric acid complexation method using microwaves include the following steps. Calculated quantities of $\mathrm{Ce}\left(\mathrm{NO}_{3}\right)_{3} \cdot 6 \mathrm{H}_{2} \mathrm{O}$, $\mathrm{Zr}\left(\mathrm{NO}_{3}\right)_{4} \cdot 5 \mathrm{H}_{2} \mathrm{O} / \mathrm{Y}\left(\mathrm{NO}_{3}\right)_{3} \cdot 6 \mathrm{H}_{2} \mathrm{O}$, and citric acid were added to deionized water [28], and the mixed solution was continuously stirred for $5 \mathrm{~min}$ in a water bath at $60{ }^{\circ} \mathrm{C}$ until it became transparent. This solution was then calcined at $600{ }^{\circ} \mathrm{C}$ in air for $4 \mathrm{~h}$ using a microwave muffle furnace (CEM Business Enterprise, America, phoenix standard unit).

\subsection{Characterization}

X-ray diffraction (XRD) patterns were recorded on a Rigaku D/max-1200 diffractometer ( $\mathrm{Cu} K_{\alpha}$ irradiation), operating at 30 $\mathrm{mA}$ and $40 \mathrm{kV}$. The diffraction patterns were recorded in the $2 \theta$ range of $20^{\circ}$ to $80^{\circ}$ with a step size of $0.02^{\circ}$. The crystal phases were ascertained using the software of MDI Jade 5.0 and the particle size was calculated from the main diffraction peaks using the Scherrer formula. Further, the lattice constant " $a$ " was calculated using the principal diffraction peak (111) based on the following equation [35]:

$$
\begin{gathered}
a=d \sqrt{h^{2}+k^{2}+l^{2}} \\
d=\frac{\lambda}{2 \sin \theta}
\end{gathered}
$$

here, $d$ is the inter-planar spacing and $\theta$ corresponds to the angle of the diffraction peak (111).

$\mathrm{N}_{2}$ adsorption-desorption isotherms were recorded on an automatic adsorption instrument (ASAP2020) at $-196^{\circ} \mathrm{C}$. Prior to analysis, the sample was degassed under high vacuum at 300 ${ }^{\circ} \mathrm{C}$ for $2 \mathrm{~h}$. The specific surface of the samples was calculated using the Brunauer-Emmett-Teller (BET) method.

The X-ray photoelectron spectra (XPS) of the samples were 
generated with a monochromatic $\mathrm{Al}-K_{a}$ excitation spectrometer. The carbon $\mathrm{C}-\mathrm{H}$ photopeak at $284.6 \mathrm{eV}$ was used for correcting the binding energies.

The Raman spectra were collected on a Via Reflex Raman spectrometer with a refrigerated CCD detector using an $\mathrm{Ar}^{+}$ laser with a $514 \mathrm{~nm}$ emission line at room temperature.

The redox behavior of the catalysts was analyzed by temperature programmed reduction (TPR) using a thermal conductivity detector (TCD) in order to measure the consumption of $\mathrm{H}_{2}$. The catalyst sample $(50 \mathrm{mg}$ ) was pretreated by calcination in $5 \% \mathrm{O}_{2} / \mathrm{Ar}$ for $60 \mathrm{~min}$ at $400{ }^{\circ} \mathrm{C}$, after which it was cooled to $100^{\circ} \mathrm{C}$ in Ar. Lastly, the temperature was increased to $900{ }^{\circ} \mathrm{C}$ at a ramp rate of $10^{\circ} \mathrm{C} / \mathrm{min}$ in a $10 \% \mathrm{H}_{2} / \mathrm{Ar}$ flow.

The oxygen storage capacity (OSC) of the $\mathrm{Ce}_{0.75} \mathrm{Zr}_{0.25} \mathrm{O}_{2}$ and $\mathrm{Ce}_{0.75} \mathrm{Y}_{0.25} \mathrm{O}_{2-\delta}$ samples was also evaluated by $\mathrm{CO}$ pulse injection using a microreactor system. Before measurement, $50 \mathrm{mg}$ of the sample was firstly treated in a flow of $20 \% \mathrm{O}_{2} / \mathrm{He}(30$ $\mathrm{mL} / \mathrm{min}$ ) for $1 \mathrm{~h}$ at $500{ }^{\circ} \mathrm{C}$. Later, this material was cooled down to $450{ }^{\circ} \mathrm{C}$ in a He flow. A pulse of pure CO gas was introduced for $10 \mathrm{~s}$ every $6 \mathrm{~min}$ through a six-port valve with a measuring ring $(50 \mu \mathrm{mol})$ at $450{ }^{\circ} \mathrm{C}$. Ten sequences of CO pulses were employed in $1 \mathrm{~h}$. The total OSC (TOSC) was calculated by summing the OSC of 10 CO pulses, which was indicated as $\mu \mathrm{mol}$ of [0] per gram of catalyst $(\mu \mathrm{mol}[0] / g)$.

\subsection{Catalytic behavior evaluation}

The catalytic behavior of the samples during $\mathrm{CH}_{3} \mathrm{SH}$ decomposition was analyzed at atmospheric pressure in a home-made tubular fixed-bed reactor. The catalyst samples $(0.2 \mathrm{~g})$ with a particle size of $0.25-0.42 \mathrm{~mm}$ were loaded into the quartz reactor. The $\mathrm{CH}_{3} \mathrm{SH}$ decomposition reaction was conducted using a feed gas of $1 \% \mathrm{CH}_{3} \mathrm{SH} / \mathrm{N}_{2}$ at $30 \mathrm{~mL} / \mathrm{min}$. The concentration of $\mathrm{CH}_{3} \mathrm{SH}$ in the gas stream was evaluated using a two GC gas chromatograph with two flame ionization detectors (FIDs), one thermal conductivity detector (TCD), and one flame photometric detector (FPD).

\section{Results and discussion}

\subsection{Crystal structure and textural properties}

\subsection{1. $X R D$}

The XRD patterns of $\mathrm{Ce}_{1-x} \mathrm{Zr}_{x} \mathrm{O}_{2}, \mathrm{Ce}_{1-x} \mathrm{Y}_{x} \mathrm{O}_{2-\delta}(x=0.25,0.50$, 0.75 , and 1.00), and $\mathrm{CeO}_{2}$ are shown in Fig. 1. The pattern of $\mathrm{CeO}_{2}$ matched well with the reference pattern (PDF 34-0394), which is an indication of the cubic fluorite-like structure of $\mathrm{CaF}_{2}$ [36]. As for the $\mathrm{Ce}_{1-x} \mathrm{Zr}_{x} \mathrm{O}_{2}$ and $\mathrm{Ce}_{1-x} \mathrm{Y}_{x} \mathrm{O}_{2-\delta}$ samples $(x=0.25$, 0.50 , and 0.75$)$, the diffraction peaks indexed to the reflections of (111), (200), (220), (331), (222), (400), (331), and (420) planes were observed, thus implying that the typical fluorite-like cubic structure is well maintained after being doped with heteroatoms ( $\mathrm{Zr}$ and $\mathrm{Y}$ ). Moreover, it could be seen that no phases assigned to $\mathrm{Zr}$ and $\mathrm{Y}$ species were detected in the patterns of $\mathrm{Ce}_{1-x} \mathrm{Zr}_{x} \mathrm{O}_{2}$ or $\mathrm{Ce}_{1-x} \mathrm{Y}_{x} \mathrm{O}_{2-\delta}$. This phenomenon may be due to the following two reasons. Both $\mathrm{Zr}$ and $\mathrm{Y}$ entered into the lattice of $\mathrm{CeO}_{2}$, forming homogeneous solid solutions [37]. Second, some Zr or Y species were highly dispersed with very small crystallites and/or presented an amorphous structure, much below the XRD detection limit [38,39]. In addition, the diffraction peak intensities of $\mathrm{Ce}_{1-x} \mathrm{Zr}_{x} \mathrm{O}_{2}$ and $\mathrm{Ce}_{1-x} \mathrm{Y}_{x} \mathrm{O}_{2-\delta}$ were slightly weaker than those of $\mathrm{CeO}_{2}$, which may be related to the
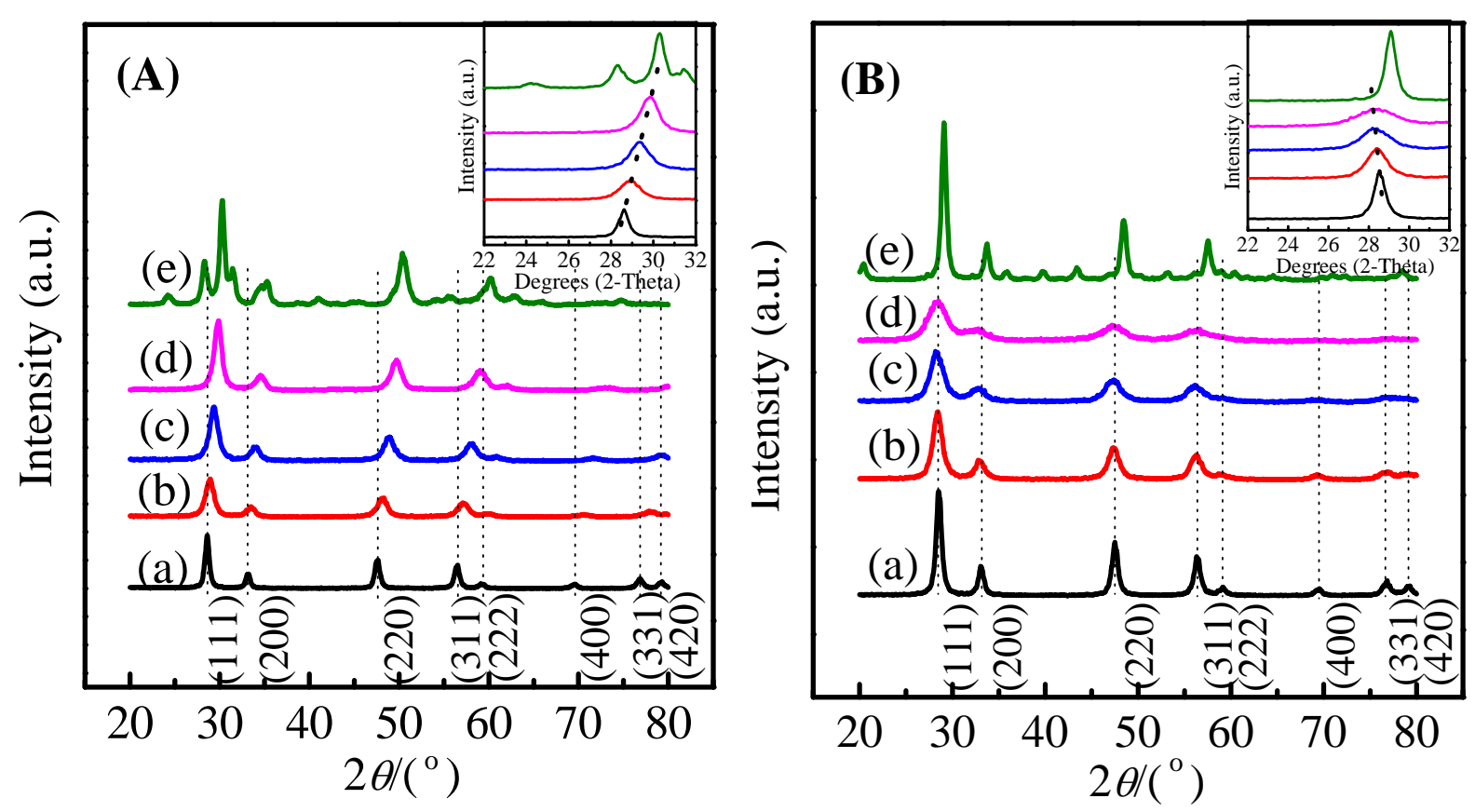

Fig. 1. (A) $\mathrm{XRD}$ patterns of $\mathrm{CeO}_{2}$ (a), $\mathrm{Ce}_{0.75} \mathrm{Zr}_{0.25} \mathrm{O}_{2}$ (b), $\mathrm{Ce}_{0.5} \mathrm{Zr}_{0.5} \mathrm{O}_{2}$ (c), $\mathrm{Ce}_{0.25} \mathrm{Zr}_{0.75} \mathrm{O}_{2}$ (d), and $\mathrm{ZrO}_{2}$ (e). (B) $\mathrm{XRD}$ patterns of $\mathrm{CeO}_{2}$ (a), $\mathrm{Ce}_{0.75} \mathrm{Y}_{0.25} \mathrm{O}_{2-\delta}$ (b), $\mathrm{Ce}_{0.50} \mathrm{Y}_{0.50} \mathrm{O}_{2-\delta}$ (c), $\mathrm{Ce}_{0.25} \mathrm{Y}_{0.75} \mathrm{O}_{2-\delta}(\mathrm{d})$, and $\mathrm{Y}_{2} \mathrm{O}_{3}(\mathrm{e})$. 
insertion of $\mathrm{Zr}$ and $\mathrm{Y}$ cations into the lattice of $\mathrm{CeO}_{2}$. According to Fig. 1 (inset), the diffraction peak belonging to $\mathrm{Ce}_{1-\mathrm{x}} \mathrm{Zr}_{x} \mathrm{O}_{2}$ gradually shifted towards larger $2 \theta$ values with increasing $\mathrm{Zr}$ loading, as shown in Fig. 1(A), whereas the corresponding diffraction of $\mathrm{Ce}_{1-x} \mathrm{Y}_{x} \mathrm{O}_{2-\delta}$ shifted to smaller $2 \theta$ values. These differences in the diffraction angles $(2 \theta)$ of $\mathrm{Ce}_{1-x} \mathrm{Zr}_{x} \mathrm{O}_{2}$ and $\mathrm{Ce}_{1-x} \mathrm{Y}_{x} \mathrm{O}_{2-\delta}$ are closely associated with the fact that the radius of the $\mathrm{Zr}^{4+}$ ion $(0.84 \AA)$ is lesser than that of the $\mathrm{Ce}^{4+}$ ion $(0.97 \AA)$, but the radius of $\mathrm{Y}^{3+}(1.03 \AA)$ is slightly larger than that of the $\mathrm{Ce}^{4+}$ ion. The insertion of $\mathrm{Zr}^{4+}$ with its smaller radius into the ceria unit cell will cause lattice contraction, whereas the incorporation of $\mathrm{Y}^{3+}$ with its larger radius into the $\mathrm{CeO}_{2}$ unit cell will lead to lattice expansion. The corresponding lattice parameters and crystallite sizes of $\mathrm{Ce}_{1-x} \mathrm{Y}_{x} \mathrm{O}_{2-\delta}, \mathrm{Ce}_{1-x} \mathrm{Zr}_{x} \mathrm{O}_{2}(x=0.25,0.50$, 0.75 , and 1.00), and $\mathrm{CeO}_{2}$ are shown in Table 1. Obviously, the lattice parameters of $\mathrm{Ce}_{0.75} \mathrm{Zr}_{0.25} \mathrm{O}_{2}$ (5.348 $\AA$ ), $\mathrm{Ce}_{0.50} \mathrm{Zr}_{0.50} \mathrm{O}_{2}$

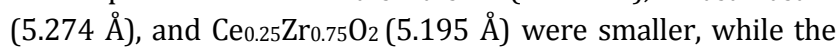
parameters of $\mathrm{Ce}_{0.75} \mathrm{Y}_{0.25} \mathrm{O}_{2-\delta}(5.410 \AA), \mathrm{Ce}_{0.50} \mathrm{Y}_{0.50} \mathrm{O}_{2-\delta}(5.407 \AA)$, and $\mathrm{Ce}_{0.25} \mathrm{Y}_{0.75} \mathrm{O}_{2-\delta}(5.403 \AA)$ were larger than that of $\mathrm{CeO}_{2}$ $(5.400 \AA)$. Besides, the diffraction peaks of $\mathrm{Ce}_{1-\mathrm{x}} \mathrm{Zr}_{x} \mathrm{O}_{2}$ and $\mathrm{Ce}_{1-x} \mathrm{Y}_{x} \mathrm{O}_{2-\delta}$ were wider than that of $\mathrm{CeO}_{2}$, which indicates that the crystallite sizes of $\mathrm{Ce}_{1-\chi} \mathrm{Zr}_{x} \mathrm{O}_{2}$ and $\mathrm{Ce}_{1-\chi} \mathrm{Y}_{x} \mathrm{O}_{2-\delta}$ are smaller than that of $\mathrm{CeO}_{2}$, which in turn is due to the inserted heteroatoms effectively suppressing the growth of crystallites. According to the results calculated using the Scherrer equation, the corresponding crystallite sizes of $\mathrm{CeO}_{2}, \mathrm{Ce}_{0.75} \mathrm{Zr}_{0.25} \mathrm{O}_{2}$, $\mathrm{Ce}_{0.50} \mathrm{Zr}_{0.50} \mathrm{O}_{2}$, Ce ${ }_{0.25} \mathrm{Zr}_{0.75} \mathrm{O}_{2}$, $\mathrm{Ce}_{0.75} \mathrm{Y}_{0.25} \mathrm{O}_{2-\delta}, \mathrm{Ce}_{0.50} \mathrm{Y}_{0.50} \mathrm{O}_{2-\delta}$, and $\mathrm{Ce}_{0.25} \mathrm{Y}_{0.75} \mathrm{O}_{2-\delta}$ were $12.0,7.1,6.8,7.6,7.5,5.9$, and $4.5 \mathrm{~nm}$, respectively, as shown in Table 1.

From the above-described XRD results, we can conclude that $\mathrm{Zr}$ and $\mathrm{Y}$ cations are inserted into the ceria lattice. However, it is not clear whether separate $\mathrm{Zr}$ and $\mathrm{Y}$ species with small crystallites or amorphous structures are formed on the surface of $\mathrm{Ce}_{1-x} \mathrm{Zr}_{x} \mathrm{O}_{2}$ and $\mathrm{Ce}_{1-x} \mathrm{Y}_{x} \mathrm{O}_{2-\delta}$.

\subsubsection{XPS}

Table 1

The specific surface areas, crystallite sizes, and lattice parameters of the oxide solid solutions, $\mathrm{Ce}_{1-x} \mathrm{Zr}_{x} \mathrm{O}_{2}$ and $\mathrm{Ce}_{1-x} \mathrm{Y}_{x} \mathrm{O}_{2-\delta}$.

\begin{tabular}{lccc}
\hline $\begin{array}{l}\text { Oxide } \\
\text { composition }\end{array}$ & $\begin{array}{c}\text { Surface area } \\
\left(\mathrm{m}^{2} / \mathrm{g}\right)\end{array}$ & $\begin{array}{c}\text { Crystallite } \\
\text { size }^{\mathrm{b}}(\mathrm{nm})\end{array}$ & $\begin{array}{c}\text { Lattice parameter } \\
\text { " } a^{\prime}\end{array}$ \\
\hline $\mathrm{CeO}_{2}$ & 42.8 & 12.0 & 5.400 \\
$\mathrm{Ce}_{0.75} \mathrm{Zr}_{0.25} \mathrm{O}_{2}$ & 57.4 & 7.1 & 5.348 \\
$\mathrm{Ce}_{0.50} \mathrm{Zr}_{0.50} \mathrm{O}_{2}$ & 35.3 & 6.8 & 5.274 \\
$\mathrm{Ce}_{0.25} \mathrm{Zr}_{0.75} \mathrm{O}_{2}$ & 30.2 & 7.6 & 5.195 \\
$\mathrm{ZrO}_{2}$ & 6.9 & 14.5 & 5.111 \\
$\mathrm{Ce}_{0.75} \mathrm{Y}_{0.25} \mathrm{O}_{2-\delta}$ & 50.71 & 7.5 & 5.410 \\
$\mathrm{Ce}_{0.50} \mathrm{Y}_{0.50} \mathrm{O}_{2-\delta}$ & 31.9 & 5.9 & 5.407 \\
$\mathrm{Ce}_{0.25} \mathrm{Y}_{0.75} \mathrm{O}_{2-\delta}$ & 21.9 & 4.5 & 5.403 \\
$\mathrm{Y}_{2} \mathrm{O}_{3}$ & 11.6 & 13.6 & 5.316 \\
\hline
\end{tabular}

a Determined by BET.

${ }^{\mathrm{b}}$ Determined by MDI Jade 5.0 and the Scherrer equation.

To demonstrate that separate $\mathrm{Zr}$ and $\mathrm{Y}$ species do not exist on the surface of $\mathrm{Ce}_{1-x} \mathrm{Zr}_{x} \mathrm{O}_{2}$ and $\mathrm{Ce}_{1-x} \mathrm{Y}_{x} \mathrm{O}_{2-\delta}$, XPS was used to characterize $\mathrm{ZrO}_{2}, \mathrm{Ce}_{0.75} \mathrm{Zr}_{0.25} \mathrm{O}_{2}, \mathrm{Ce} 0.50 \mathrm{Zr}_{0.50} \mathrm{O}_{2}, \mathrm{Ce}_{0.25} \mathrm{Zr}_{0.75} \mathrm{O}_{2}$, $\mathrm{Y}_{2} \mathrm{O}_{3}, \mathrm{Ce}_{0.75} \mathrm{Y}_{0.25} \mathrm{O}_{2-\delta}, \mathrm{Ce}_{0.50} \mathrm{Y}_{0.50} \mathrm{O}_{2-\delta}$, and $\mathrm{Ce}_{0.25} \mathrm{Y}_{0.75} \mathrm{O}_{2-\delta}$ to evaluate the composition and chemical state on their surfaces. $\mathrm{Zr} 3 d \mathrm{XPS}$ spectra of $\mathrm{ZrO}_{2}, \mathrm{Ce}_{0.75} \mathrm{Zr}_{0.25} \mathrm{O}_{2}, \mathrm{Ce}_{0.50} \mathrm{Zr}_{0.50} \mathrm{O}_{2}$, and $\mathrm{Ce}_{0.25} \mathrm{Zr}_{0.75 \mathrm{O}_{2}}$ are shown in Fig. 2(A), while $\mathrm{Y} 3 d$ XPS spectra of $\mathrm{Y}_{2} \mathrm{O}_{3}$, $\mathrm{Ce}_{0.75} \mathrm{Y}_{0.25} \mathrm{O}_{2-\delta}$, $\mathrm{Ce}_{0.50} \mathrm{Y}_{0.50} \mathrm{O}_{2-\delta}$, and $\mathrm{Ce}_{0.25} \mathrm{Y}_{0.75} \mathrm{O}_{2-\delta}$ are shown in Fig. 2(B). It is clear that both the Zr $3 d$ and Y $3 d$ XPS spectra could be deconvoluted with two peaks, which are associated with the contribution of two spin-orbit components. As shown

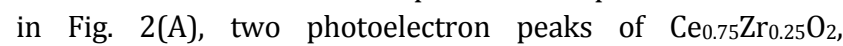
$\mathrm{Ce}_{0.50} \mathrm{Zr}_{0.50} \mathrm{O}_{2}$, and $\mathrm{Ce}_{0.25} \mathrm{Zr}_{0.75} \mathrm{O}_{2}$ originated from the contributions of $\mathrm{Zr} 3 d_{3 / 2}$ and $\mathrm{Zr} 3 d_{5 / 2}$, which were located at 181.8 and $184.2 \mathrm{eV}$, respectively. The photoelectron peaks centered at 156.7 and $158.8 \mathrm{eV}$ have been attributed to $\mathrm{Y} 3 d_{5 / 2}$ and $\mathrm{Y} 3 d_{3 / 2}$ [40], respectively. It could be seen in Table 2 that the relative contents of $\mathrm{Zr}$ in $\mathrm{Ce}_{0.75} \mathrm{Zr}_{0.25} \mathrm{O}_{2}, \mathrm{Ce}_{0.50} \mathrm{Zr}_{0.50} \mathrm{O}_{2}$, and $\mathrm{Ce}_{0.25} \mathrm{Zr}_{0.75} \mathrm{O}_{2}$ were $25.9,51.8$, and 75.4 wt $\%$, respectively; meanwhile, the

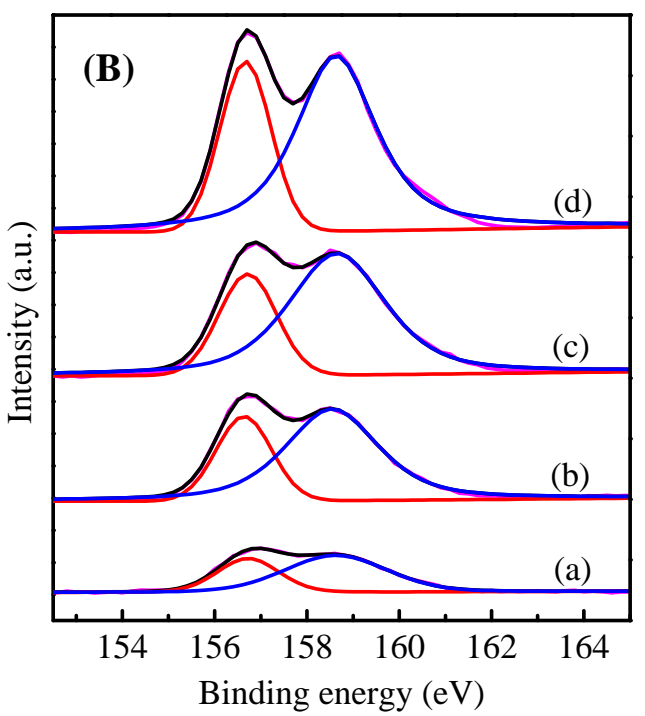

Fig. 2. (A) $\mathrm{Zr} 3 d \mathrm{XPS}$ spectra of $\mathrm{Ce}_{0.75} \mathrm{Zr}_{0.25} \mathrm{O}_{2}$ (a), $\mathrm{Ce}_{0.50} \mathrm{Zr}_{0.50} \mathrm{O}_{2}$ (b), $\mathrm{Ce}_{0.25} \mathrm{Zr}_{0.75} \mathrm{O}_{2}$ (c), and $\mathrm{ZrO}_{4}$ (d). (B) Y $3 d X P S$ spectra of Ce $\mathrm{X}_{0.75} \mathrm{Y}_{0.25} \mathrm{O}_{2-\delta}$ (a), $\mathrm{Ce}_{0.50} \mathrm{Y}_{0.50} \mathrm{O}_{2-\delta}$ (b), $\mathrm{Ce}_{0.75} \mathrm{Y}_{0.25} \mathrm{O}_{2-\delta}(\mathrm{c})$, and $\mathrm{Y}_{2} \mathrm{O}_{3}(\mathrm{~d})$. 
Table 2

Relative contents of $\mathrm{Zr}$ and $\mathrm{Y}$ in the $\mathrm{Ce}_{1-x} \mathrm{Zr}_{x} \mathrm{O}_{2}$ and $\mathrm{Ce}_{1-x} \mathrm{Y}_{x} \mathrm{O}_{2-\delta}$ samples.

\begin{tabular}{lccc}
\hline Sample & $\begin{array}{c}\text { Relative content } \\
\text { of } \mathrm{Zr}^{\mathrm{a}}(\%)\end{array}$ & Sample & $\begin{array}{c}\text { Relative content } \\
\text { of } \mathrm{Y}^{\mathrm{b}}(\%)\end{array}$ \\
\hline $\mathrm{Ce}_{0.75} \mathrm{Zr}_{0.25} \mathrm{O}_{2}$ & 25.9 & $\mathrm{Ce}_{0.75} \mathrm{Y}_{0.25} \mathrm{O}_{2-\delta}$ & 24.4 \\
$\mathrm{Ce}_{0.50} \mathrm{Zr}_{0.50} \mathrm{O}_{2}$ & 51.8 & $\mathrm{Ce}_{0.50} \mathrm{Y}_{0.50} \mathrm{O}_{2-\delta}$ & 52.6 \\
$\mathrm{Ce}_{0.25} \mathrm{Zr}_{0.75} \mathrm{O}_{2}$ & 75.4 & $\mathrm{Ce}_{0.25} \mathrm{Y}_{0.75} \mathrm{O}_{2-\delta}$ & 76.2 \\
$\mathrm{ZrO}_{4}$ & 100.0 & $\mathrm{Y}_{2} \mathrm{O}_{3}$ & 100.0 \\
\hline
\end{tabular}

a Calculated by the ratio of the total area of $\mathrm{Ce}_{1-\mathrm{x}} \mathrm{Zr}_{x} \mathrm{O}_{2}$ to $\mathrm{ZrO}_{2}$ in the $\mathrm{Zr}$ $3 d$ region.

The areas were calculated according to the following equation, $A_{\mathrm{zr}}=$ $A\left(\mathrm{Zr} 3 d_{5 / 2}\right)+A\left(\mathrm{Zr} 3 d_{3 / 2}\right)$, using a CasaXPS processing program.

b Calculated by the ratio of the total area of $\mathrm{Ce}_{1-x} \mathrm{Y}_{x} \mathrm{O}_{2-\delta}$ to $\mathrm{Y}_{2} \mathrm{O}_{3}$ in the $\mathrm{Y}$ $3 d$ region.

The areas were calculated according to the following equation, $A_{\mathrm{Y}}=A(\mathrm{Y}$ $\left.3 d_{5 / 2}\right)+A\left(Y 3 d_{3 / 2}\right)$, using a CasaXPS processing program.

corresponding $\mathrm{Y}$ content in $\mathrm{Ce} 0.75 \mathrm{Y}_{0.25} \mathrm{O}_{2-\delta}, \mathrm{Ce}_{0.50} \mathrm{Y}_{0.50} \mathrm{O}_{2-\delta}$, and $\mathrm{Ce}_{0.25} \mathrm{Y}_{0.75} \mathrm{O}_{2-\delta}$ were 24.4, 52.6, and $76.2 \mathrm{wt} \%$, respectively, which are almost consistent with the theoretically calculated values $(25,50$, and $75 \mathrm{wt} \%$, respectively). Combining with the results of XRD characterization (Fig. 1), which indicate that the diffraction peaks ascribed to isolated $\mathrm{Zr}$ and $\mathrm{Y}$ species are not observed in the patterns of $\mathrm{Ce}_{1-x} \mathrm{Zr}_{x} \mathrm{O}_{2}$ and $\mathrm{Ce}_{1-x} \mathrm{Y}_{x} \mathrm{O}_{2-\delta}$, it should be concluded that all the doped heteroatoms ( $\mathrm{Zr}$ and $\mathrm{Y}$ ) are highly dispersed in two types of samples, forming homogeneous solid solutions.

The areas were calculated according to the following equation, $A_{\mathrm{Y}}=A\left(\mathrm{Y} 3 d_{5 / 2}\right)+A\left(\mathrm{Y} 3 d_{3 / 2}\right)$, using a CasaXPS processing program.

\subsubsection{Raman spectroscopy}

Raman spectroscopy is one of the most effective methods to obtain a deep insight into the formation of oxygen vacancies in cerium-based catalysts [30,31,41-43]. To better understand the structural differences between $\mathrm{Ce}_{1-x} \mathrm{Zr}_{x} \mathrm{O}_{2}$ and $\mathrm{Ce}_{1-x} \mathrm{Y}_{x} \mathrm{O}_{2-\delta}$, these materials were characterized using Raman spectroscopy, which is more sensitive than XRD, to investigate and discuss the changes occurring in the solid solutions. As shown in Fig. 3(A) and (B), only one intense peak centered at $464 \mathrm{~cm}^{-1}$, assigned to the F2g symmetry Raman vibration mode [44], was observed in $\mathrm{CeO}_{2}$, indicating its cubic fluorite-like structure. Moreover, the band at $464 \mathrm{~cm}^{-1}$ was well expressed in the Raman spectra of $\mathrm{Ce}_{0.75} \mathrm{Zr}_{0.25} \mathrm{O}_{2}, \mathrm{Ce}_{0.50} \mathrm{Zr}_{0.50} \mathrm{O}_{2}, \mathrm{Ce}_{0.25} \mathrm{Zr}_{0.75} \mathrm{O}_{2}$, $\mathrm{Ce}_{0.75} \mathrm{Y}_{0.25} \mathrm{O}_{2-\delta}$, and $\mathrm{Ce}_{0.50} \mathrm{Y}_{0.50} \mathrm{O}_{2-\delta}$ when the heteroatoms ( $\mathrm{Zr}$ and $\mathrm{Y}$ ) were inserted into the lattice of $\mathrm{CeO}_{2}$, thus indicating that the cubic fluorite-like structure is still preserved in these catalysts. However, there were significant changes in the Raman peak intensities and widths, especially $\mathrm{Ce}_{0.50} \mathrm{Y}_{0.50} \mathrm{O}_{2-\delta}$, which may be closely associated with the lattice distortion and/or the formation of oxygen vacancies in them; they might be attributed to the insertion of heteroatoms ( $\mathrm{Zr}$ and $\mathrm{Y}$ ) with different radii and valence states. As can be seen from Fig. 3 (inset), a broad and weak band located at $615 \mathrm{~cm}^{-1}$ was found in the spectra of both $\mathrm{Ce}_{1-x} \mathrm{Zr}_{x} \mathrm{O}_{2}$ and $\mathrm{Ce}_{1-x} \mathrm{Y}_{x} \mathrm{O}_{2-\delta}$; it may be assigned to structural defects arising from lattice distortion (expansion and/or contraction) owing to the disparity of ionic radius between $\mathrm{Ce}^{4+}$ and the doped cations $\left(\mathrm{Zr}^{4+}\right.$ and $\left.\mathrm{Y}^{3+}\right)[45,46]$. Another weak band centered at around $560 \mathrm{~cm}^{-1}$ was clearly observed in the spectrum of $\mathrm{Ce}_{1-x} \mathrm{Y}_{x} \mathrm{O}_{2-\delta}$, but not in the spectrum of $\mathrm{Ce}_{1-x} \mathrm{Zr}_{x} \mathrm{O}_{2}$. The band was closely associated with the formation of oxygen vacancies $[45,46]$, which originated due to the replacement of $\mathrm{Ce}^{4+}$ by $\mathrm{Y}^{3+}$ to maintain charge neutrality [47].

Based on the Raman results, it can be deduced that structural defects are generated within both $\mathrm{Ce}_{1-x} \mathrm{Zr}_{x} \mathrm{O}_{2}$ and $\mathrm{Ce}_{1-x} \mathrm{Y}_{x} \mathrm{O}_{2-\delta}$; however, the significant difference between $\mathrm{Ce}_{1-x} \mathrm{Zr}_{x} \mathrm{O}_{2}$ and $\mathrm{Ce}_{1-x} \mathrm{Y}_{x} \mathrm{O}_{2-\delta}$ is that oxygen vacancies are formed only in Y-doped samples, but not in Zr-doped samples.

\subsection{Relationship between surface lattice oxygen and catalytic activity}

\subsubsection{Catalytic activity}

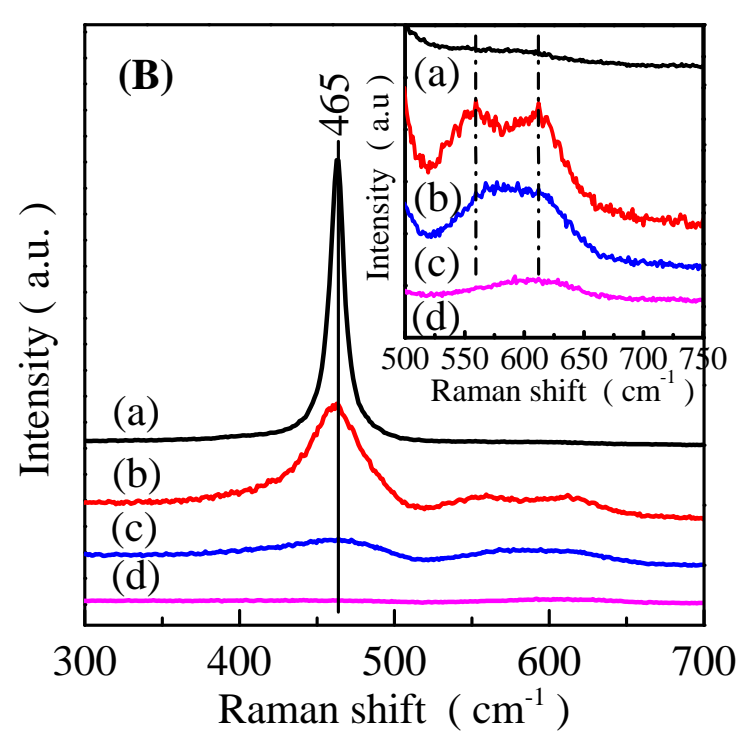

Fig. 3. (A) Raman spectra of $\mathrm{CeO}_{2}$ (a), $\mathrm{Ce}_{0.75} \mathrm{Zr}_{0.25} \mathrm{O}_{2}$ (b), $\mathrm{Ce}_{0.5} \mathrm{Zr}_{0.5} \mathrm{O}_{2}$ (c), and $\mathrm{Ce}_{0.25} \mathrm{Zr}_{0.75} \mathrm{O}_{2}$ (d). (B) Raman spectra of $\mathrm{CeO}_{2}$ (a), $\mathrm{Ce}_{0.75} \mathrm{Y}_{0.25} \mathrm{O}_{2-\delta}$ (b), $\mathrm{Ce}_{0.50} \mathrm{Y}_{0.50} \mathrm{O}_{2-\delta}(\mathrm{c})$, and $\mathrm{Ce}_{0.25} \mathrm{Y}_{0.75} \mathrm{O}_{2-\delta}(\mathrm{d})$. 

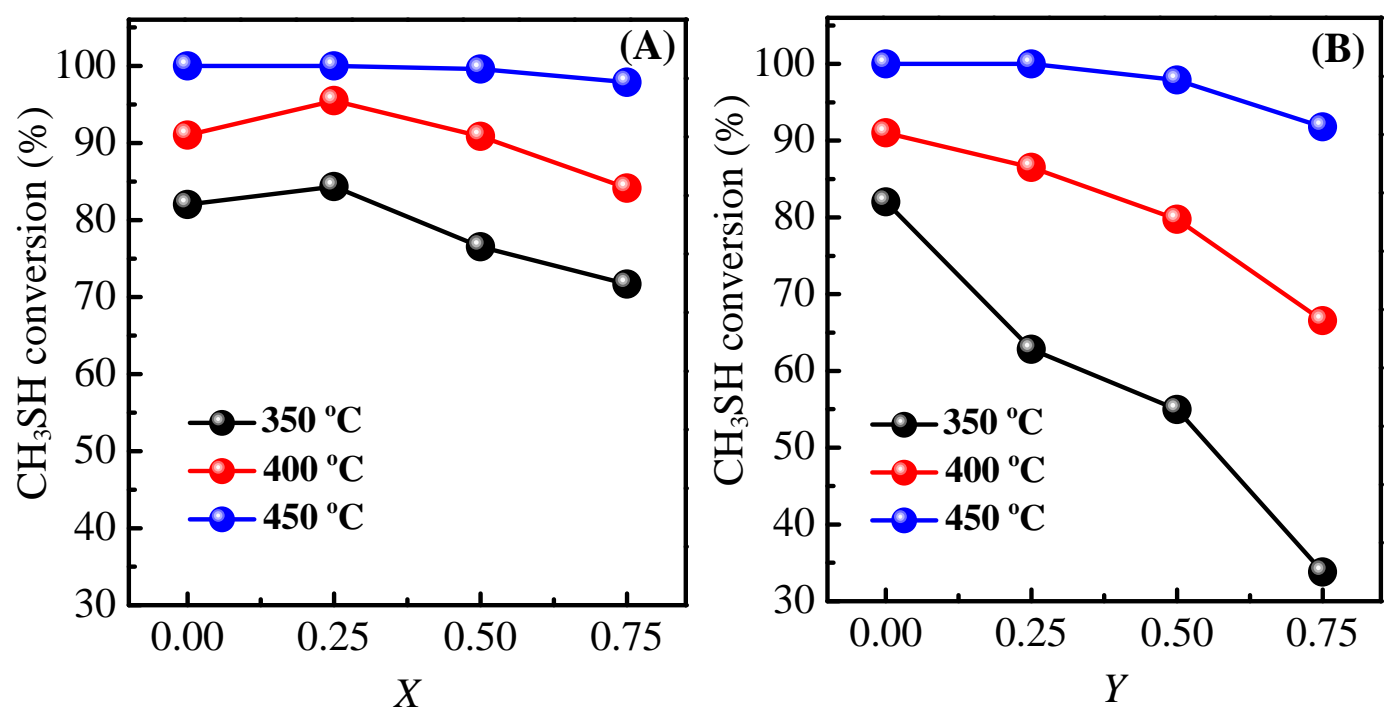

Fig. 4. Conversion of $\mathrm{CH}_{3} \mathrm{SH}$ over $\mathrm{Ce}_{1-x} \mathrm{Zr}_{x} \mathrm{O}_{2}(\mathrm{~A})$ and $\mathrm{Ce}_{1-x} \mathrm{Y}_{x} \mathrm{O}_{2-\delta}$ (B) samples $(x=0,0.25,0.50$, and 0.75$)$ at 350 , 400, and $450{ }^{\circ} \mathrm{C}$.

Fig. 4 shows the conversion of $\mathrm{CH}_{3} \mathrm{SH}$ over $\mathrm{Ce}_{1-x} \mathrm{Y}_{x} \mathrm{O}_{2-\delta}$, $\mathrm{Ce}_{1-x} \mathrm{Zr}_{x} \mathrm{O}_{2}(x=0.25,0.50$, and 0.75$)$, and $\mathrm{CeO}_{2}$ at 350,400 , and $450{ }^{\circ} \mathrm{C}$. According to Fig. 4, $\mathrm{CH}_{3} \mathrm{SH}$ could be completely converted over the $\mathrm{Ce}_{1-x} \mathrm{Zr}_{x} \mathrm{O}_{2}(x=0,0.25$, and 0.50$)$ and $\mathrm{Ce}_{1-x} \mathrm{Y}_{x} \mathrm{O}_{2-\delta}$ $(x=0$ and 0.25 ) catalysts when the reaction temperature was as high as $450{ }^{\circ} \mathrm{C}$. Interestingly, the conversion of $\mathrm{CH}_{3} \mathrm{SH}$ at 350 , 400 , and $450{ }^{\circ} \mathrm{C}$ initially increased with $\mathrm{Zr}$ loading ( $x=0.25$ ) and then decreased upon further addition ( $x=0.50$ and 0.75 ). However, within the reaction temperature range of 350 to 450 ${ }^{\circ} \mathrm{C}$, the conversion of $\mathrm{CH}_{3} \mathrm{SH}$ gradually decreased with increasing Y loading. Based on the above results, we can conclude that the addition of appropriate amounts of zirconium can improve the catalytic activity, while doped yttrium is not conducive to $\mathrm{CH}_{3} \mathrm{SH}$ conversion.

To analyze the reason for the difference in the activities of $\mathrm{Ce}_{1-x} \mathrm{Zr}_{x} \mathrm{O}_{2}$ and $\mathrm{Ce}_{1-x} \mathrm{Y}_{x} \mathrm{O}_{2-\delta}$, the best catalysts, $\mathrm{Ce}_{0.75} \mathrm{Zr}_{0.25} \mathrm{O}_{2}$, $\mathrm{Ce}_{0.75} \mathrm{Y}_{0.25} \mathrm{O}_{2-\delta}$, and $\mathrm{CeO}_{2}$ were chosen to explore the relation- ship between the oxygen species and catalytic activity via a series of characterization techniques.

\subsection{2. $X P S$}

The $01 s$ and Ce $3 d$ XPS spectra of $\mathrm{Ce}_{0.75} \mathrm{Zr}_{0.25} \mathrm{O}_{2}$, $\mathrm{Ce}_{0.75} \mathrm{Y}_{0.25} \mathrm{O}_{2-\delta}$, and $\mathrm{CeO}_{2}$ were recorded and presented in Fig. 5. Further, the corresponding data (surface lattice oxygen content, $\mathrm{Ce}^{3+}$ content, as well as the ratio of $\mathrm{Ce}^{3+}$ to $\mathrm{Ce}^{4+}$ ), calculated based on the XPS analysis of the three samples, are shown in Table 3. As displayed in Fig. 5(A), two photoelectron peaks were observed for $\mathrm{CeO}_{2}, \mathrm{Ce}_{0.75} \mathrm{Zr}_{0.25} \mathrm{O}_{2}$, and $\mathrm{Ce}_{0.75} \mathrm{Y}_{0.25} \mathrm{O}_{2-\delta}$, suggesting two types of oxygen species on their surfaces. The peak with the lower binding energy (529-530 eV) is the contribution of surface lattice oxygen (named as $\mathrm{O}_{\text {s-latt}}$ ), while the other peak with higher binding energy, in the range of 531-533 eV, has been ascribed to surface adsorbed oxygen (denoted as $\mathrm{O}_{\mathrm{s} \text {-ads) }}$ $[8,48]$. It could be seen by comparing Fig. 5(A) and Table 3 that
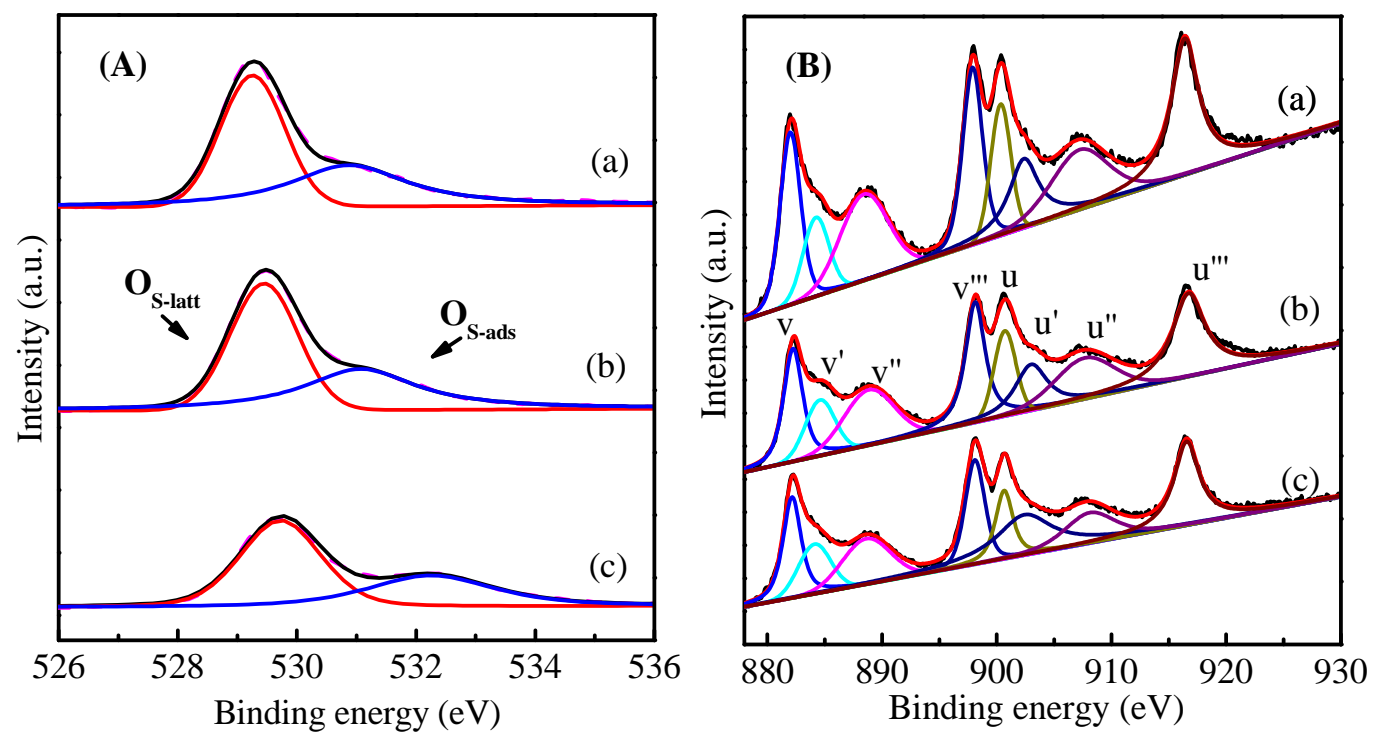

Fig. 5. $01 s(\mathrm{~A})$ and $\mathrm{Ce} 3 d(\mathrm{~B})$ core level XPS spectra of $\mathrm{CeO}_{2}(\mathrm{a}), \mathrm{Ce}_{0.75} \mathrm{Zr}_{0.25} \mathrm{O}_{2}$ (b), and $\mathrm{Ce}_{0.75} \mathrm{Y}_{0.25} \mathrm{O}_{2-\delta}$ (c). 
Table 3

$01 s$ and Ce $3 d$ relative contents in $\mathrm{CeO}_{2}, \mathrm{Ce}_{0.75} \mathrm{Zr}_{0.25} \mathrm{O}_{2}$, and $\mathrm{Ce}_{0.75} \mathrm{Y}_{0.25} \mathrm{O}_{2-\delta}$.

\begin{tabular}{|c|c|c|c|}
\hline \multirow{2}{*}{ Samples } & \multirow{2}{*}{$\begin{array}{l}\text { Relative amount } \\
\text { of } \mathrm{O}_{\text {s-latt }}{ }^{\mathrm{a}}\end{array}$} & \multicolumn{2}{|c|}{ Relative content of Ce } \\
\hline & & $\mathrm{Ce}^{3+} / \mathrm{Ce}^{4+c}$ & Relative content of $\mathrm{Ce}^{3+\mathrm{b}}$ \\
\hline$\overline{\mathrm{CeO}_{2}}$ & 1.0000 & 0.2123 & 0.1751 \\
\hline $\mathrm{Ce}_{0.75} \mathrm{Zr}_{0.25} \mathrm{O}_{2}$ & 0.9995 & 0.2126 & 0.1753 \\
\hline $\mathrm{Ce}_{0.75} \mathrm{Y}_{0.25} \mathrm{O}_{2-\delta}$ & 0.9182 & 0.3688 & 0.2695 \\
\hline
\end{tabular}

aThe area of surface lattice oxygen of $\mathrm{CeO}_{2}$ was assigned to be 1.0000 , so as to compare with those of $\mathrm{Ce}_{0.75} \mathrm{Zr}_{0.25} \mathrm{O}_{2}$ and $\mathrm{Ce}_{0.75} \mathrm{Y}_{0.25} \mathrm{O}_{2-\delta}$.

${ }^{\mathrm{b}}$ The relative content of $\mathrm{Ce}^{3+}$ was calculated according to Eqs. (1)-(3).

c $\mathrm{The}^{3+}{ }^{3+} / \mathrm{Ce}^{4+}$ ratio was calculated according to Eq. (4).

the Os-latt relative content of $\mathrm{Ce}_{0.75} \mathrm{Zr}_{0.25 \mathrm{O}_{2}}$ was almost the same as that in $\mathrm{CeO}_{2}$ and an analogous phenomenon was reported by Nelson and coworkers [49]. However, the $\mathrm{O}_{\text {s-latt }}$ relative content of $\mathrm{Ce}_{0.75} \mathrm{Y}_{0.25} \mathrm{O}_{2}$ was significantly lower than those of $\mathrm{CeO}_{2}$ and $\mathrm{Ce}_{0.75} \mathrm{Zr}_{0.25} \mathrm{O}_{2}$. In comparison with $\mathrm{CeO}_{2}$, the difference in the surface lattice oxygen contents of $\mathrm{Ce}_{0.75} \mathrm{Zr}_{0.25} \mathrm{O}_{2}$ and $\mathrm{Ce}_{0.75} \mathrm{Y}_{0.25} \mathrm{O}_{2}$ can be explained as follows. The incorporation of $\mathrm{Zr}^{4+}$ ions does not require charge compensation via the release of surface lattice oxygen $\left(\mathrm{O}_{\text {s-latt }}\right)$ to maintain charge neutrality as the chemical valence state of $\mathrm{Zr}^{4+}$ and $\mathrm{Ce}^{4+}$ is the same; on the other hand, when a $\mathrm{Y}^{3+}$ ion is inserted into the ceria lattice to replace $\mathrm{Ce}^{4+}$, in order to achieve charge neutrality, release of surface lattice oxygen (Os-latt) to compensate for the charge difference between $\mathrm{Y}^{3+}$ ions and $\mathrm{Ce}^{4+}$ ions is indispensable. An analogous phenomenon was also observed for the substitution of $\mathrm{Ce}^{4+}$ ions with other low valence ions $\left(\mathrm{M}^{2+/ 3+}\right)$ [47].

The Ce $3 d$ XPS spectra of $\mathrm{CeO}_{2}, \mathrm{Ce}_{0.75} \mathrm{Zr}_{0.25} \mathrm{O}_{2}$, and $\mathrm{Ce}_{0.75} \mathrm{Y}_{0.25} \mathrm{O}_{2-\delta}$ are presented in Fig. 5(B). It is obvious that the Ce $3 d$ XPS spectra of the three samples could be deconvoluted into 8 peaks, which were composed of pairs of spin orbit doublets. In general, the six peaks labeled as v, v"', v'", u, u", and u"' can be thought of as originating from the contributions of the $\mathrm{Ce}^{4+}$ state, whereas the peaks marked as $\mathrm{v}^{\prime}$ and $\mathrm{u}^{\prime}$ are ascribed to the contributions of $\mathrm{Ce}^{3+}[50]$. According to previous studies
$[24,51]$, the formulae listed below were employed to calculate the proportion of $\mathrm{Ce}^{3+}$ ions in the catalysts:

$$
\begin{gathered}
\text { Relative content of } \mathrm{Ce}^{3+}=\left\{A_{\mathrm{v}^{\prime}}+A_{\mathrm{u}^{\prime}}\right\} / \\
\left\{A_{\mathrm{v}}+A_{\mathrm{v}^{\prime \prime}}+A_{\mathrm{v}^{\prime \prime}+}+A_{\mathrm{u}}+A_{\mathrm{u}^{\prime \prime}}+A_{\mathrm{u}^{\prime \prime}}+A_{\mathrm{v}^{\prime}}+A_{\mathrm{u}^{\prime}}\right\}
\end{gathered}
$$

The ratio of $\mathrm{Ce}^{3+}$ and $\mathrm{Ce}^{4+}$ was calculated according to the following equation:

$$
\mathrm{Ce}^{3+} / \mathrm{Ce}^{4+}=\left\{A_{\mathrm{v}^{\prime}}+A_{\mathrm{u}^{\prime}}\right\} /\left\{A_{\mathrm{v}}+A_{\mathrm{v}^{\prime \prime}}+A_{\mathrm{v}^{\prime \prime}}+A_{\mathrm{u}}+A_{\mathrm{u}^{\prime \prime}}+A_{\mathrm{u}^{\prime \prime}}\right\}
$$

here, $A$ is the Ce $3 d$ photoelectron peak area and the results are shown in Table 3. It is noticeable that there is a significant decrease in all the Ce $3 d$ photoelectron peak intensities of $\mathrm{Ce}_{0.75} \mathrm{Zr}_{0.25} \mathrm{O}_{2}$ and $\mathrm{Ce}_{0.75} \mathrm{Y}_{0.25} \mathrm{O}_{2-\delta}$ with respect to $\mathrm{CeO}_{2}$, which may be due to the fact that the Ce ions have been substituted by $\mathrm{Zr}$ and $\mathrm{Y}$ ions. As can be seen from Table 3, the ratio of $\mathrm{Ce}^{3+}$ ions to $\mathrm{Ce}^{4+}$ ions and the relative content of $\mathrm{Ce}^{3+}$ in $\mathrm{Ce}_{0.75} \mathrm{Zr}_{0.25} \mathrm{O}_{2}$ were comparable to those of $\mathrm{CeO}_{2}$; however, the corresponding $\mathrm{Ce}^{3+} / \mathrm{Ce}^{4+}$ ratio and $\mathrm{Ce}^{3+}$ relative content in $\mathrm{Ce}_{0.75} \mathrm{Y}_{0.25} \mathrm{O}_{2}$ were far higher than those of $\mathrm{CeO}_{2}$. Generally, the switch change between $\mathrm{Ce}^{4+}$ and $\mathrm{Ce}^{3+}$ is usually accompanied the discharge of lattice oxygen [24]. The changes in the ratio of $\mathrm{Ce}^{3+} / \mathrm{Ce}^{4+}$ and the difference in the relative content of $\mathrm{Ce}^{3+}$ between $\mathrm{Ce}_{0.75} \mathrm{Zr}_{0.25} \mathrm{O}_{2}$ and $\mathrm{Ce}_{0.75} \mathrm{Y}_{0.25} \mathrm{O}_{2-\delta}$ should be related to the fact that some lattice oxygen can be removed from the latter, but not from the former. These results coincided with the results of $01 s$ characterization (Fig. 5(A) and Table 3).

From Fig. 4, we can determine that the conversion of $\mathrm{CH}_{3} \mathrm{SH}$ over the three catalysts at reaction temperatures of 350 to 450 ${ }^{\circ} \mathrm{C}$ is in the order of $\mathrm{Ce}_{0.75} \mathrm{Zr}_{0.25} \mathrm{O}_{2}>\mathrm{CeO}_{2}>\mathrm{Ce}_{0.75} \mathrm{Y}_{0.25} \mathrm{O}_{2-\delta}$. Combined with the results of XPS, it can be deduced that the surface lattice oxygen $\left(\mathrm{O}_{\text {s-latt}}\right)$ may be associated with $\mathrm{CH}_{3} \mathrm{SH}$ catalytic conversion.

To further investigate the action of $\mathrm{O}_{\text {s-latt }}$ in cerium oxides in $\mathrm{CH}_{3} \mathrm{SH}$ decomposition, an example of $\mathrm{CH}_{3} \mathrm{SH}$ transformation over $\mathrm{CeO}_{2}$ was carried out at $450{ }^{\circ} \mathrm{C}$ for $10 \mathrm{~h}$. Meanwhile, the corresponding $01 s$ XPS spectra at different reaction times are shown in Fig. 6. The $0_{\text {s-latt }}$ relative contents in cerium dioxides at different reaction times are tabulated in Table 4. Obviously,
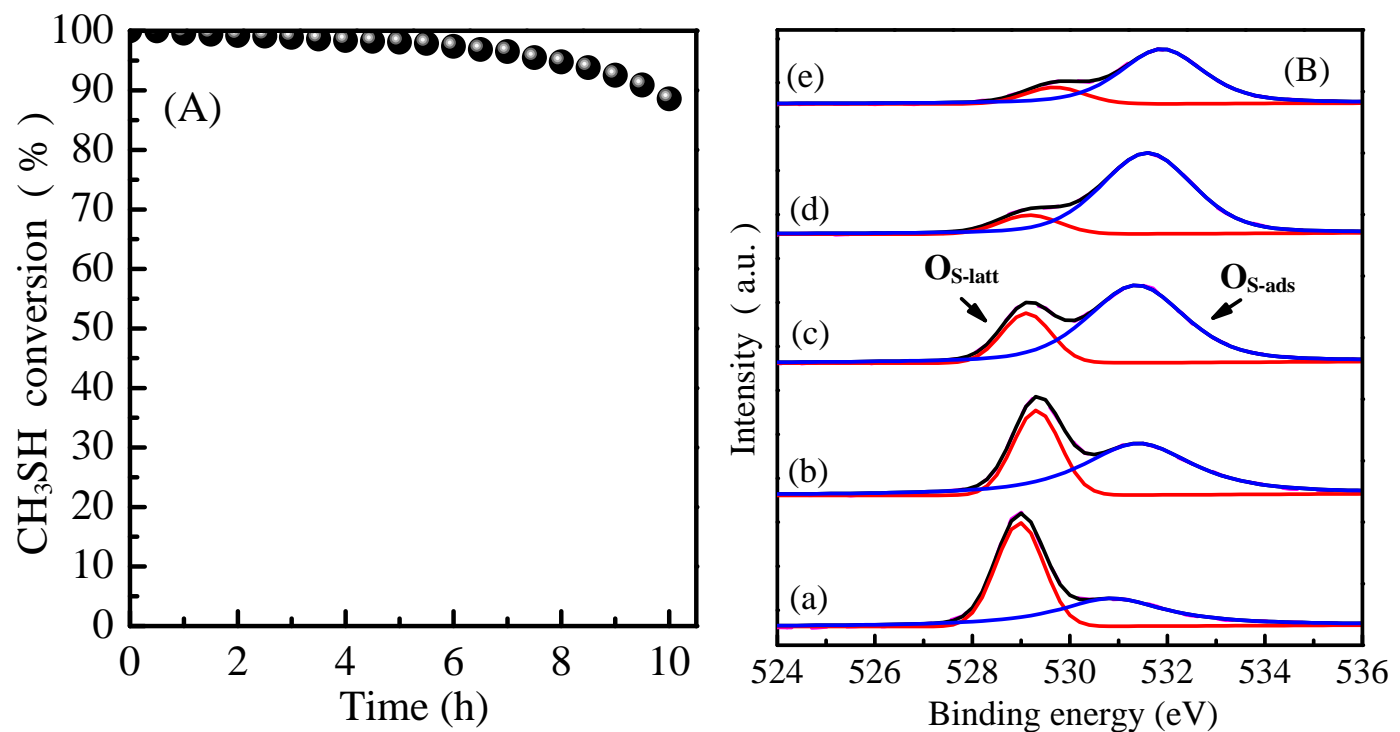

Fig. 6. (A) $\mathrm{CH}_{3} \mathrm{SH}$ conversion during a time-on-stream test at $450{ }^{\circ} \mathrm{C}$ over $\mathrm{CeO}_{2}$; (B) $01 \mathrm{~s} \mathrm{XPS}_{\text {spectra }}$ of $\mathrm{CeO}_{2}$ before and after a time-on-stream test at $450^{\circ} \mathrm{C}$ for various reaction times. (a) Fresh; (b) $1 \mathrm{~h}$; (c) $3 \mathrm{~h}$; (d) $6 \mathrm{~h}$; (e) $10 \mathrm{~h}$. 
Table 4

Relative contents of surface lattice oxygen $\left(\mathrm{O}_{\text {s-latt }}\right)$ and $\mathrm{Ce}^{3+}$ in $\mathrm{CeO}_{2}$ before and after a time-on-stream test for different time periods.

\begin{tabular}{lcc}
\hline Samples & $\begin{array}{c}\text { Relative content of } \mathrm{O}_{\text {s-latt }}{ }^{\mathrm{a}} \\
(\%)\end{array}$ & $\begin{array}{c}\text { Relative content of } \mathrm{Ce}^{3+\mathrm{b}} \\
(\%)\end{array}$ \\
\hline $\mathrm{CeO}_{2}(0 \mathrm{~h})^{\mathrm{c}}$ & 100 & 16.0 \\
$\mathrm{CeO}_{2}(1 \mathrm{~h})^{\mathrm{c}}$ & 81.4 & 19.0 \\
$\mathrm{CeO}_{2}(3 \mathrm{~h})^{\mathrm{c}}$ & 49.8 & 29.5 \\
$\mathrm{CeO}_{2}(6 \mathrm{~h})^{\mathrm{c}}$ & 22.8 & 37.5 \\
$\mathrm{CeO}_{2}(10 \mathrm{~h})^{\mathrm{c}}$ & 19.8 & 41.9 \\
\hline
\end{tabular}

a The relative content of surface lattice oxygen $\left(\mathrm{O}_{\text {s-latt }}\right)$ was calculated from the $01 s$ spectra of $\mathrm{CeO}_{2}$ before and after a time-on-stream test; the $\mathrm{O}_{\text {s-latt }}$ relative content of $\mathrm{CeO}_{2}$ was set as $100 \%$.

b The relative content of $\mathrm{Ce}^{3+}$ was calculated according to Eqs. (1)-(3), using the $\mathrm{Ce} 3 d$ spectra of $\mathrm{CeO}_{2}$ before and after a time-on-stream test.

${ }^{c}$ Reaction time of the time-on-stream test is included in the brackets.

$\mathrm{CH}_{3} \mathrm{SH}$ conversion over $\mathrm{CeO}_{2}$ decreased with the progress of the online reaction process, while the $\mathrm{O}_{\text {s-latt }}$ content in this catalyst declined. After $10 \mathrm{~h}$, the conversion rate of methyl mercaptan over $\mathrm{CeO}_{2}$ dropped to $88 \%$ and the Os-latt content decreased to $20 \%$. In contrast, during the reaction process, Os-ads experienced a slight increase. The reason was that the $\mathrm{O}_{\mathrm{s}-\text { latt }}$ content in $\mathrm{CeO}_{2}$ could be consumed during the reaction, causing the formation of a greater amount of oxygen vacancies. These vacancies were able to catch some hydrate and carbonate species ( $\mathrm{CO}$ and $\mathrm{CO}_{2}$ ), which could be held responsible for the slight increase in the content of $\mathrm{O}_{\mathrm{s} \text {-ads }}$ [52-54]. Therefore, the above results further show that $\mathrm{O}_{\text {s-latt }}$ directly influences $\mathrm{CH}_{3} \mathrm{SH}$ conversion.

The relationship between $\mathrm{O}_{s-l a t t}$ and $\mathrm{CH}_{3} \mathrm{SH}$ catalytic conversion was further analyzed from the Ce $3 d$ XPS spectra of $\mathrm{CeO}_{2}$ at different reaction times, as shown in Fig. 7. In addition, the corresponding computed results are also shown in Table 4. It

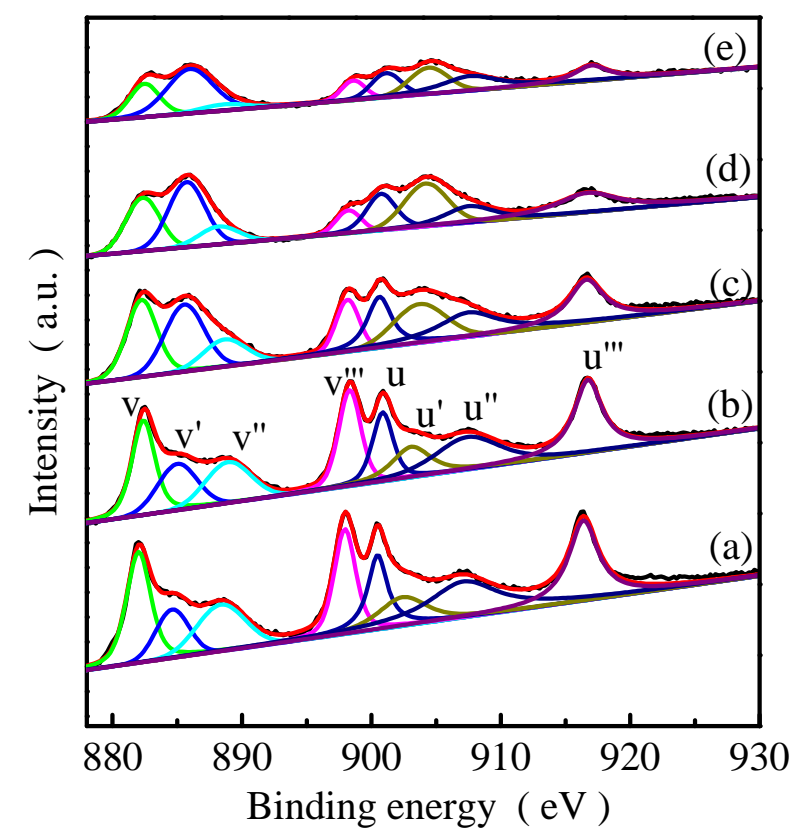

Fig. 7. Ce $3 d \mathrm{XPS}$ spectra of $\mathrm{CeO}_{2}$ before and after a time-on-stream test at $450{ }^{\circ} \mathrm{C}$ for various time periods. (a) Fresh; (b) $1 \mathrm{~h}$; (c) $3 \mathrm{~h}$; (d) $6 \mathrm{~h}$; (e) $10 \mathrm{~h}$. could be seen that photoelectron peak intensity ascribed to $\mathrm{Ce}^{4+}$ gradually declined with an increase in the online reaction time, while two other peaks attributed to the $\mathrm{Ce}^{3+}$ state increased with increasing time on the stream. The probable reason is that a large number of $\mathrm{Ce}^{4+}$ cations are transformed into $\mathrm{Ce}^{3+}$ cations after the online reaction period. According to literature, the shift between $\mathrm{Ce}^{4+}$ and $\mathrm{Ce}^{3+}$ is usually accompanied by oxygen release in the cerium lattice [24] and thus, $\mathrm{O}_{\text {s-latt }}$ can take part in the methanethiol conversion process.

According to these results acquired from active experiments as well as other characterization techniques, two conclusions can be made. Firstly, Os-latt, rather than Os-ads, plays an important role in $\mathrm{CH}_{3} \mathrm{SH}$ conversion over ceria-based materials. Second, the difference in activity between the two heteroatoms ( $\mathrm{Zr}$ and $\mathrm{Y}$ )-doped cerium based catalysts $\left(\mathrm{Ce}_{0.75} \mathrm{Zr}_{0.25} \mathrm{O}_{2}\right.$ and $\mathrm{Ce}_{0.75} \mathrm{Y}_{0.25} \mathrm{O}_{2-\delta}$ ) is because of the incorporation of $\mathrm{Y}^{3+}$ into the $\mathrm{CeO}_{2}$ lattice causing the removal of $\mathrm{O}_{\text {s-latt }}$ for maintaining electric neutrality. The insertion of $\mathrm{Zr}^{4+}$ ions need not release surface lattice oxygen $\left(\mathrm{O}_{\mathrm{s} \text {-latt }}\right)$ to maintain charge neutrality due to the same chemical valence states of $\mathrm{Zr}^{4+}$ and $\mathrm{Ce}^{4+}$. Thus, Ce $0.75 \mathrm{Zr}_{0.25} \mathrm{O}_{2}$ exhibits better catalytic activity.

\subsection{3. $H_{2}-T P R$}

The $\mathrm{H}_{2}$-TPR patterns of $\mathrm{CeO}_{2}, \quad \mathrm{Ce}_{0.75} \mathrm{Zr}_{0.25} \mathrm{O}_{2}$, and $\mathrm{Ce}_{0.75} \mathrm{Y}_{0.25} \mathrm{O}_{2-\delta}$ are presented in Fig. 8 to investigate their redox properties. It could be found that $\mathrm{CeO}_{2}$ exhibited two obvious reduction peaks in range of $400-800{ }^{\circ} \mathrm{C}$, ascribed to the reduction of surface oxygen and bulk oxygen species separately [55]. Compared with $\mathrm{CeO}_{2}$, both $\mathrm{Ce}_{0.75} \mathrm{Zr}_{0.25} \mathrm{O}_{2}$ and $\mathrm{Ce}_{0.75} \mathrm{Y}_{0.25} \mathrm{O}_{2-\delta}$ exhibited just a single reduction peak in the region between 400 and $650{ }^{\circ} \mathrm{C}$. This is because when the temperature is increased from 100 to $900{ }^{\circ} \mathrm{C}$, surface and bulk reduction occur concurrently; in other words, there is no clear distinction between the

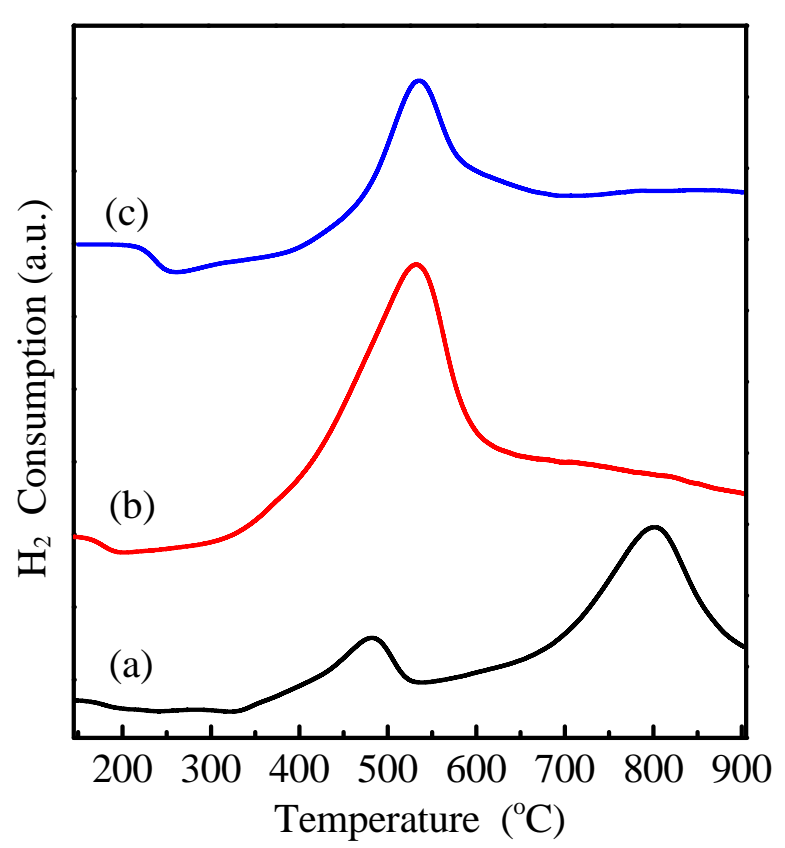

Fig. 8. $\mathrm{H}_{2}$ - TPR profiles of $\mathrm{CeO}_{2}$ (a), $\mathrm{Ce}_{0.75} \mathrm{Zr}_{0.25} \mathrm{O}_{2}$ (b), and $\mathrm{Ce}_{0.75} \mathrm{Y}_{0.25} \mathrm{O}_{2-\delta}$ (c). 
surface and bulk peaks, which suggests that the oxygen species located within the subsurface or bulk of these two samples can migrate to the surface of the catalysts as surface oxygen to be consumed [56,57]. Moreover, it was noted that the $\mathrm{H}_{2}$ consumption of $\mathrm{Ce}_{0.75} \mathrm{Zr}_{0.25} \mathrm{O}_{2}$ at low temperatures (around $500{ }^{\circ} \mathrm{C}$ ) was larger than those of $\mathrm{CeO}_{2}$ and $\mathrm{Ce}_{0.75} \mathrm{Y}_{0.25} \mathrm{O}_{2-\delta}$, thus showing that more oxygen species have been reduced.

Based on the characterization results of XPS and $\mathrm{H}_{2}$-TPR, the difference in the catalytic activities of $\mathrm{CeO}_{2}, \mathrm{Ce}_{0.75} \mathrm{Zr}_{0.25} \mathrm{O}_{2}$, and $\mathrm{Ce}_{0.75} \mathrm{Y}_{0.25} \mathrm{O}_{2-\delta}$ can be explained as follows. When $\mathrm{Ce}_{0.75} \mathrm{Zr}_{0.25} \mathrm{O}_{2}$ is compared with $\mathrm{CeO}_{2}$, the $\mathrm{O}_{\mathrm{s}-\text { latt }}$ amounts of $\mathrm{CeO}_{2}$ and $\mathrm{Ce}_{0.75} \mathrm{Zr}_{0.25} \mathrm{O}_{2}$ are almost the same, whereas the redox properties of the latter are better than those of the former. Therefore, the catalytic activity of $\mathrm{Ce}_{0.75} \mathrm{Zr}_{0.25} \mathrm{O}_{2}$ is higher than that of $\mathrm{CeO}_{2}$. As for $\mathrm{Ce}_{0.75} \mathrm{Zr}_{0.25} \mathrm{O}_{2}$ and $\mathrm{Ce}_{0.75} \mathrm{Y}_{0.25} \mathrm{O}_{2-\delta}$, their redox properties are almost the same, while the $\mathrm{O}_{s-\text { latt }}$ amount in $\mathrm{Ce}_{0.75} \mathrm{Zr}_{0.25} \mathrm{O}_{2}$ is higher than that in $\mathrm{Ce}_{0.75} \mathrm{Y}_{0.25} \mathrm{O}_{2-\delta}$. Accordingly, the catalytic activity of $\mathrm{Ce}_{0.75} \mathrm{Zr}_{0.25} \mathrm{O}_{2}$ is higher than that of $\mathrm{Ce}_{0.75} \mathrm{Y}_{0.25} \mathrm{O}_{2-\delta}$. The difference in the activities of $\mathrm{Ce}_{0.75} \mathrm{Y}_{0.25} \mathrm{O}_{2-\delta}$ and $\mathrm{CeO}_{2}$ is related to the fact that the $\mathrm{Os}_{\text {s-latt }}$ amount of the former is lower than that of the latter.

\subsection{The relationship between bulk lattice oxygen migration and catalytic stability}

\subsubsection{Catalytic stability}

The catalytic conversions of $\mathrm{CH}_{3} \mathrm{SH}$ with reaction time below $450{ }^{\circ} \mathrm{C}$ over $\mathrm{CeO}_{2}, \mathrm{Ce}_{0.75} \mathrm{Zr}_{0.25} \mathrm{O}_{2}$, and $\mathrm{Ce}_{0.75} \mathrm{Y}_{0.25} \mathrm{O}_{2-\delta}$ are shown in Fig. 9. Interestingly, the catalytic stability of $\mathrm{Ce} 0.75 \mathrm{Y}_{0.25} \mathrm{O}_{2-\delta}$ obviously improved, when compared to those of $\mathrm{Ce}_{0.75} \mathrm{Zr}_{0.25} \mathrm{O}_{2}$ and $\mathrm{CeO}_{2}$, while there was not much change in the catalytic stability over $\mathrm{CeO}_{2}$ and $\mathrm{Ce}_{0.75} \mathrm{Zr}_{0.25} \mathrm{O}_{2}$ (Fig. 9). Therefore, the difference in the catalytic life of $\mathrm{CeO}_{2}, \mathrm{Ce}_{0.75} \mathrm{Zr}_{0.25} \mathrm{O}_{2}$, and $\mathrm{Ce}_{0.75} \mathrm{Y}_{0.25} \mathrm{O}_{2-\delta}$ will be investigated and discussed in the fol-

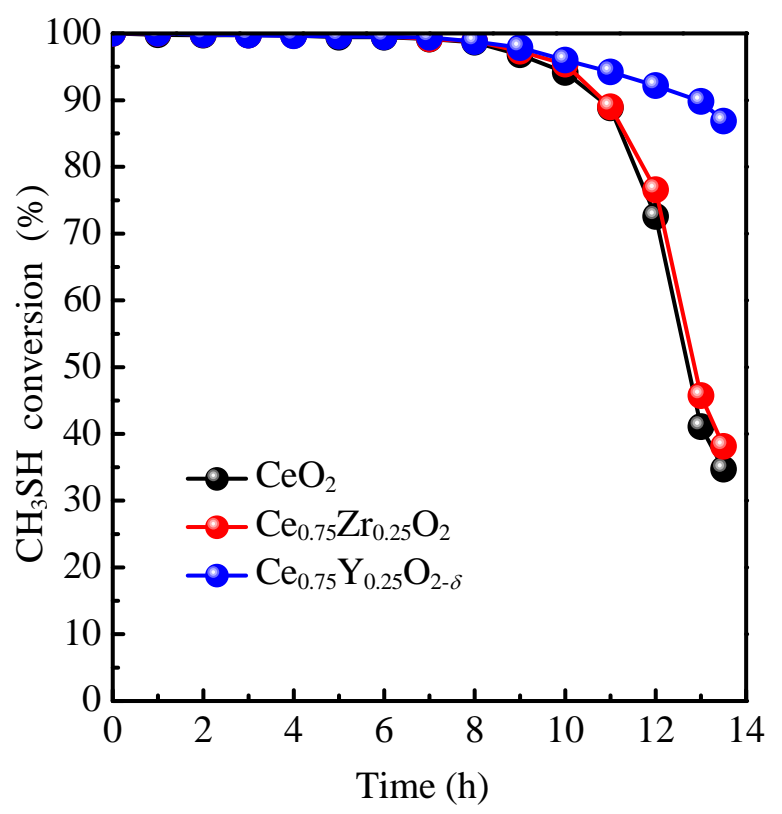

Fig. 9. $\mathrm{CH}_{3} \mathrm{SH}$ conversion as a function of reaction time at $450{ }^{\circ} \mathrm{C}$ on $\mathrm{CeO}_{2}, \mathrm{Ce}_{0.75} \mathrm{Zr}_{0.25} \mathrm{O}_{2}$, and $\mathrm{Ce}_{0.75} \mathrm{Y}_{0.25} \mathrm{O}_{2-\delta}$. lowing sections.

According to the $\mathrm{H}_{2}$-TPR characterization results (Fig. 8),

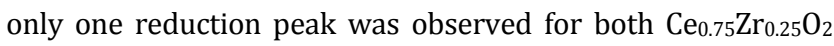
and $\mathrm{Ce}_{0.75} \mathrm{Y}_{0.25} \mathrm{O}_{2-\delta}$ in the region of $400-650{ }^{\circ} \mathrm{C}$, which indirectly verified the mobility of the subsurface or bulk lattice oxygen to the surface of catalysts as surface oxygen to be consumed $[51,52,56,57]$. Furthermore, the Raman characterization results showed that oxygen vacancies were formed only in $\mathrm{Ce}_{0.75} \mathrm{Y}_{0.25} \mathrm{O}_{2-\delta}$ but not in $\mathrm{Ce}_{0.75} \mathrm{Zr}_{0.25} \mathrm{O}_{2}$ (Fig. 3). It has been well documented that the formation of oxygen vacancies is in favor of the mobility of bulk lattice oxygen ( $\mathrm{O}_{\mathrm{B}-\mathrm{latt}}$ [ [58]. In our previous work, it was proven that the rapid deactivation of $\mathrm{CeO}_{2}$ is closely related to the depletion of $\mathrm{O}_{\text {s-latt. }}$ Thus, we postulated that the improved catalytic life of $\mathrm{Ce}_{0.75} \mathrm{Y}_{0.25} \mathrm{O}_{2-\delta}$, as compared to those of $\mathrm{Ce}_{0.75} \mathrm{Zr}_{0.25} \mathrm{O}_{2}$ and $\mathrm{CeO}_{2}$, may be due to the migration of $\mathrm{O}_{\mathrm{B}-\text { latt }}$ to rapidly replenish $\mathrm{O}_{\mathrm{s} \text {-latt. }}$ Moreover, the difference in the catalytic stabilities of $\mathrm{Ce}_{0.75} \mathrm{Zr}_{0.25} \mathrm{O}_{2}$ and $\mathrm{Ce}_{0.75} \mathrm{Y}_{0.25} \mathrm{O}_{2-\delta}$ may be

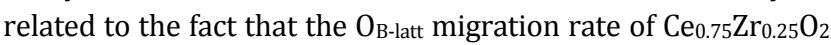
is slower than that of $\mathrm{Ce}_{0.75} \mathrm{Y}_{0.25} \mathrm{O}_{2-\delta}$ owing to the absence of oxygen vacancies.

\subsubsection{Analysis of oxide products}

In order to verify our postulation that the rapid migration of $\mathrm{O}_{\mathrm{B}-\mathrm{latt}}$ is responsible for the improvement in catalytic stability and reconfirm the role of $\mathrm{O}_{\mathrm{s} \text {-latt }}$ in improving the catalytic activity, the concentration of reaction products including $\mathrm{CO}$ and $\mathrm{CO}_{2}$ during the $\mathrm{CH}_{3} \mathrm{SH}$ catalytic conversion process over $\mathrm{Ce}_{0.75} \mathrm{Zr}_{0.25} \mathrm{O}_{2}$ and $\mathrm{Ce}_{0.75} \mathrm{Y}_{0.25} \mathrm{O}_{2-\delta}$ were investigated. The corresponding results are shown in Fig. 10. At the beginning ( $3 \mathrm{~h})$, the product concentrations of $\mathrm{CO}$ and $\mathrm{CO}_{2}$ over $\mathrm{Ce}_{0.75} \mathrm{Zr}_{0.25} \mathrm{O}_{2}$ were higher than those on $\mathrm{Ce}_{0.75} \mathrm{Y}_{0.25} \mathrm{O}_{2-\delta}$, which provided direct proof that more surface oxygen species in $\mathrm{Ce}_{0.75} \mathrm{Zr}_{0.25} \mathrm{O}_{2}$ participated in the decomposition of $\mathrm{CH}_{3} \mathrm{SH}$. This is because the

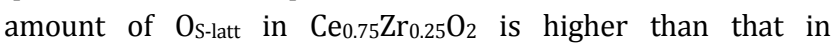

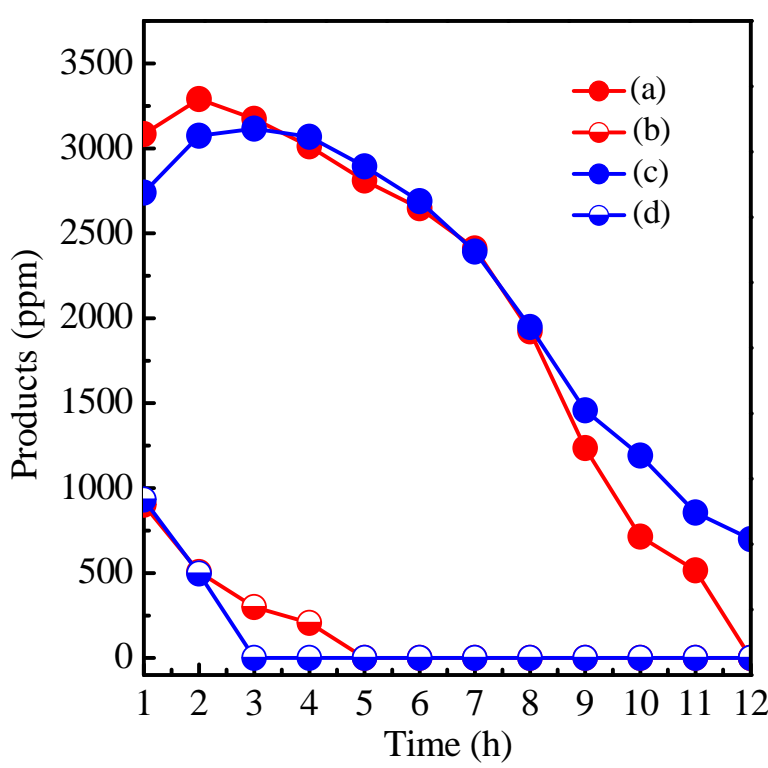

Fig. 10. $\mathrm{CO}$ (a) and $\mathrm{CO}_{2}$ (b) concentrations on $\mathrm{Ce}_{0.75} \mathrm{Zr}_{0.25} \mathrm{O}_{2}$ and $\mathrm{CO}$ (c) and $\mathrm{CO}_{2}$ (d) concentrations on $\mathrm{Ce}_{0.75} \mathrm{Y}_{0.25} \mathrm{O}_{2-\delta}$ as functions of reaction time. 
$\mathrm{Ce}_{0.75} \mathrm{Y}_{0.25} \mathrm{O}_{2-\delta}$, as shown in Fig. 5(A) and Table 3. Furthermore, with an increase in the reaction time up to $5 \mathrm{~h}$, the $\mathrm{CO}$ concentration of $\mathrm{Ce}_{0.75} \mathrm{Zr}_{0.25} \mathrm{O}_{2}$ could be compared with that of $\mathrm{Ce}_{0.75} \mathrm{Y}_{0.25} \mathrm{O}_{2-\delta}$, while a small amount of $\mathrm{CO}_{2}$ was observed in $\mathrm{Ce}_{0.75} \mathrm{Zr}_{0.25} \mathrm{O}_{2}$ but not in $\mathrm{Ce}_{0.75} \mathrm{Y}_{0.25} \mathrm{O}_{2-\delta}$. This may be because of the presence of an adequate concentration of surface lattice oxygen leading to the oxidation of CO. However, the concentration of $\mathrm{Ce}_{0.75} \mathrm{Y}_{0.25} \mathrm{O}_{2-\delta}$ was universally higher than that of $\mathrm{Ce}_{0.75} \mathrm{Zr}_{0.25} \mathrm{O}_{2}$ after $8 \mathrm{~h}$. What's more, an ideal situation was observed; $\mathrm{Ce}_{0.75} \mathrm{Y}_{0.25} \mathrm{O}_{2-\delta}$ contained more than 750 ppm of $\mathrm{CO}$ after $12 \mathrm{~h}$ of an online reaction test, whereas the corresponding $\mathrm{CO}$ concentration in $\mathrm{Ce}_{0.75} \mathrm{Zr}_{0.25} \mathrm{O}_{2}$ approached zero under the same conditions. This phenomenon can be conceivably illustrated as shown below. Os-latt is gradually consumed during the online

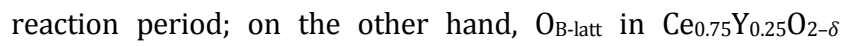
quickly migrates to the surface of the catalyst to supplement the consumed Os-latt.

\subsubsection{OSC analysis}

OSC measurements were also performed in a successive CO pulse mode to study the effect of oxygen storage capacity on bulk lattice oxygen migration (Fig. 11). The quantitative data of OSC and TOSC over $\mathrm{Ce}_{0.75} \mathrm{Zr}_{0.25} \mathrm{O}_{2}$ and $\mathrm{Ce}_{0.75} \mathrm{Y}_{0.25} \mathrm{O}_{2-\delta}$ samples are summarized in Table 5. For the first CO pulse over $\mathrm{Ce}_{0.75} \mathrm{Zr}_{0.25} \mathrm{O}_{2}$, compared with $\mathrm{Ce}_{0.75} \mathrm{Y}_{0.25} \mathrm{O}_{2-\delta}$, it could be seen that there was a greater amount of $\mathrm{CO}$ consumption and $\mathrm{CO}_{2}$ production. In addition, the OSC and TOSC of $\mathrm{Ce}_{0.75} \mathrm{Zr}_{0.25} \mathrm{O}_{2}$ were higher than those of $\mathrm{Ce}_{0.75} \mathrm{Y}_{0.25} \mathrm{O}_{2-\delta}$ (Table 5), manifesting that plenty of the most active and accessible oxygen species exist in $\mathrm{Ce}_{0.75} \mathrm{Zr}_{0.25} \mathrm{O}_{2}$ than in $\mathrm{Ce}_{0.75} \mathrm{Y}_{0.25} \mathrm{O}_{2-\delta}$. Those available oxygen species contribute to the oxidation of $\mathrm{CO}$, corresponding to the results of product analysis shown in Fig. 10, indicating the formation of more $\mathrm{CO}_{2}$ over $\mathrm{Ce}_{0.75} \mathrm{Zr}_{0.25} \mathrm{O}_{2}$ during the first several hours. However, after the third pulse, as shown in Fig. 11, $\mathrm{Ce}_{0.75} \mathrm{Y}_{0.25} \mathrm{O}_{2-\delta}$ could consume more carbon monoxide (Fig. $11(\mathrm{~A})$ ) and produce more carbon dioxide (Fig. 11(B)) as com-
Table 5

OSC and TOSC analysis of $\mathrm{Ce}_{0.75} \mathrm{Zr}_{0.25} \mathrm{O}_{2}$ and $\mathrm{Ce}_{0.75} \mathrm{Y}_{0.25} \mathrm{O}_{2-\delta}$.

\begin{tabular}{lcc}
\hline Sample & OSC ${ }^{a}(\mu \mathrm{mol}[0] / g)$ & TOSC $^{a}(\mu \mathrm{mol}[0] / g)$ \\
\hline $\mathrm{Ce}_{0.75} \mathrm{Zr}_{0.25} \mathrm{O}_{2}{ }^{\mathrm{b}}$ & 602 & 1831 \\
$\mathrm{Ce}_{0.75} \mathrm{Y}_{0.25} \mathrm{O}_{2-\delta}{ }^{\mathrm{b}}$ & 297 & 1571 \\
\hline
\end{tabular}

a Oxygen contents according to $\mathrm{CO}$ pulses

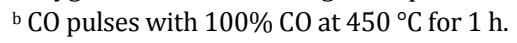

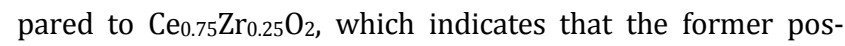
sesses greater oxygen mobility. The above results also offer direct evidence that the mobility rate of $\mathrm{O}_{\mathrm{B}-\text { latt }}$ in $\mathrm{Ce}_{0.75} \mathrm{Y}_{0.25} \mathrm{O}_{2-\delta}$ is superior to that in $\mathrm{Ce}_{0.75} \mathrm{Zr}_{0.25} \mathrm{O}_{2}$.

\subsection{Influence of valence and ionic radius on catalytic activity and stability}

Combining the above described experimental results with the relevant characterization results, the influence of the doped heteroatom's valence and ionic radius on the catalytic activity and stability for $\mathrm{CH}_{3} \mathrm{SH}$ decomposition over ceria-based catalysts will be discussed. Fig. 12 shows a schematic diagram of heteroatom (M) modified ceria-based solid solutions.

In heteroatom (M) doped ceria-based materials, doping low valence $\mathrm{M}\left(\mathrm{M}^{2+/ 3+}\right)$ ions will cause a loss of lattice oxygen, generating more quantitative oxygen vacancies, promoting the migration of bulk lattice oxygen in the catalysts so as to improve their catalytic stability; however, it is not conducive to enhancing their activity due to the removal of surface lattice oxygen. In comparison, $\mathrm{M}^{4+}$-doped cations do not lead to the loss of lattice oxygen, which is beneficial in improving the activity of ceria-based catalysts. However, they go against bulk lattice oxygen migration because of the lack of oxygen vacancies, owing to which the stability of the material deteriorates. The difference in radius between Ce and M ions leads to defect species, which couldn't work for increasing bulk lattice oxygen mobility as to improve the stability of ceria-based catalysts.
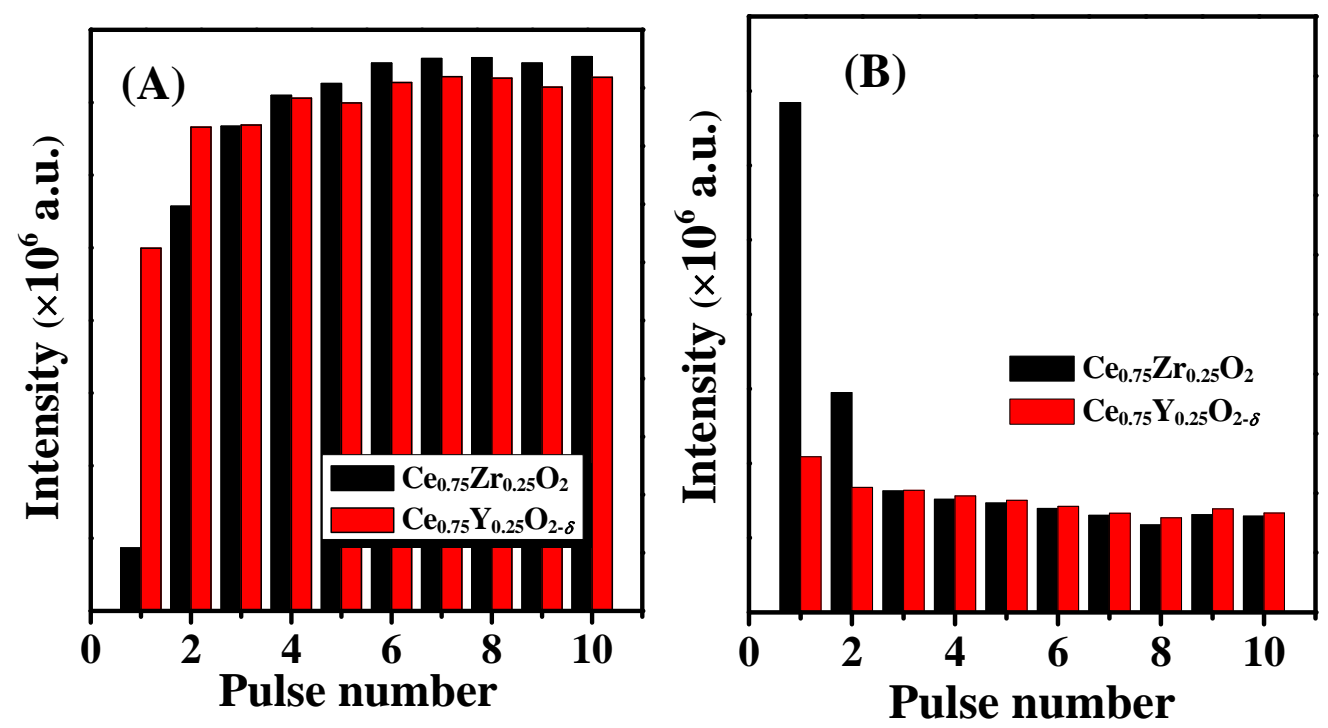

Fig. 11. The pulse signals of $\mathrm{CO}(\mathrm{A})$ and $\mathrm{CO}_{2}(\mathrm{~B})$ during a $\mathrm{CO}$ multi-pulse test over $\mathrm{Ce}_{0.75} \mathrm{Zr}_{0.25} \mathrm{O}_{2}$ and $\mathrm{Ce}_{0.75} \mathrm{Y}_{0.25} \mathrm{O}_{2-\delta}$ at $450{ }^{\circ} \mathrm{C}$. 


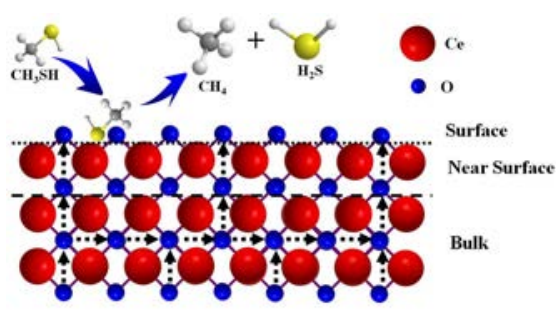

$\mathrm{CeO}_{2}$

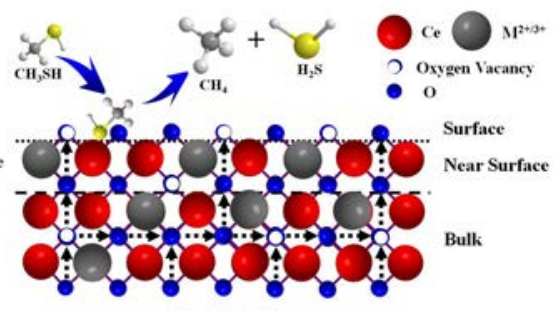

$\mathrm{Ce}_{x} \mathrm{M}_{1-x} \mathrm{O}_{2-\sigma}$

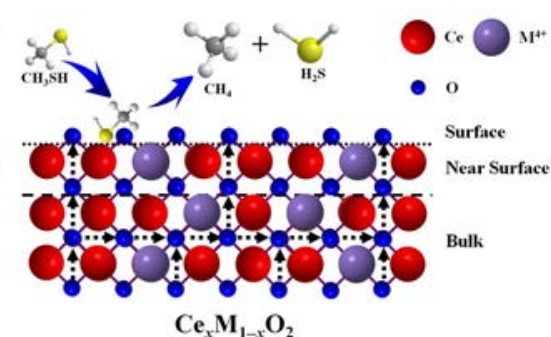

$\mathrm{Ce}_{x} \mathrm{M}_{1-x} \mathrm{O}_{2}$

Fig. 12. Schematic diagram of heteroatom modified ceria-based solid solutions.

\section{Conclusions}

In this work, a series of $\mathrm{Ce}_{1-x} \mathrm{Y}_{x} \mathrm{O}_{2-\delta}, \mathrm{Ce}_{1-x} \mathrm{Zr}_{x} \mathrm{O}_{2}(x=0.25,0.50$, 0.75 , and 1.0 ), and $\mathrm{CeO}_{2}$ catalysts were rapidly prepared by a citric acid complexation method using microwaves. The catalytic behavior of these materials for the decomposition of $\mathrm{CH}_{3} \mathrm{SH}$ was analyzed, along with a series of other characterization techniques, to investigate the role of oxygen vacancies and the relationship between the oxygen species and catalytic properties. The results showed that surface lattice oxygen plays a key role in $\mathrm{CH}_{3} \mathrm{SH}$ catalytic conversion. $\mathrm{Ce}_{0.75} \mathrm{Zr}_{0.25} \mathrm{O}_{2}$ shows higher catalytic activity for the decomposition of $\mathrm{CH}_{3} \mathrm{SH}$ due to more surface lattice oxygen and readily available oxygen species, along with better redox properties. $\mathrm{Ce}_{0.75} \mathrm{Y}_{0.25} \mathrm{O}_{2-\delta}$ exhibits better catalytic stability compared to $\mathrm{CeO}_{2}$ and $\mathrm{Ce}_{0.75} \mathrm{Zr}_{0.25} \mathrm{O}_{2}$. This is because more oxygen vacancies within $\mathrm{Ce}_{0.75} \mathrm{Y}_{0.25} \mathrm{O}_{2-\delta}$ can promote bulk lattice oxygen migration in order to replenish surface lattice oxygen and improve its catalytic stability. The valence difference between Ce and the heteroatom seriously affects the quantity of surface lattice oxygen and mobility of bulk lattice oxygen within ceria-based catalysts, thus influencing catalytic activity and stability for $\mathrm{CH}_{3} \mathrm{SH}$ conversion. Moreover, the difference in the radii of $\mathrm{Ce}$ and the heteroatom will lead to the formation of defect species that cannot promote bulk lattice oxygen mobility or improve the catalytic stability of cerium-based catalysts.

\section{References}

[1] L. Zhang, Y. X. Peng, J. Zhang, L. Chen, X. J. Meng, F. S. Xiao, Chin. J. Catal., 2016, 37, 800-809.

[2] W. M. Cai, G. H. Lu, J. He, Y. Lan, Ceram. Int, 2012, 38, 3167-3174.

[3] V. Hulea, E. Huguet, C. Cammarano, A. Lacarriere, R. Durand, C. Leroi, R. Cadours, B. Coq, Appl. Catal. B, 2014, 144, 547-553.

[4] S. Z. Zhao, H. H. Yi, X. L. Tang, F. Y. Gao, B. Zhang, Z. X. Wang, Y. R. Zuo, J. Cleaner. Prod., 2015, 87, 856-86.

[5] A. Bagreev, J. A. Menendez, I. Dukhno, Y. Tarasenko, T. J. Bandosz, Carbon, 2005, 43, 208-210.

[6] S. Bashkova, A. Bagreev, T. J. Bandosz, Catal. Today, 2005, 99, 323-328.

[7] I. A. A. C. Esteves, M. S. S. Lopes, P. M. C. Nunes, J. P. B. Mota, Separ. Purif. Technol., 2008, 62, 281-296.

[8] J. C. Lu, H. S. Hao, L. M. Zhang, Z. Z. Xu, L. P. Zhong, Y. T. Zhao, D. D. He, J. P. Liu, D. K. Chen, H. P. Pu, S. F. He, Y. M. Luo, Appl. Catal. B, 2018, 237, 185-197.

[9] E. Huguet, B. Coq, R. Durand, C. Leroi, R. Cadours, V. Hulea, Appl.
Catal. B, 2013, 134-135, 344-348.

[10] L. Altas, H. Büyükgüngör, J. Hazard Mater., 2008, 153, 462-469.

[11] A. Ryzhikov, V. Hulea, D. Tichit, C. Leroi, D. Anglerot, B. Coq, P. Trens, Appl. Catal. A, 2011, 397, 218-224.

[12] M. G. Conti-Ramsden, K. Nkrumah-Amoako, N. W. Brown, E. P. L. Roberts, Adsorption, 2013, 19, 989-996.

[13] M. Mirzaeian, A. M. Rashidi, M. Zare, R. Ghabezi, R. Lotfi, J. Nat. Gas Sci. Eng., 2014, 18, 439-445.

[14] J. Y. Liu, M. Zhao, C. H. Xu, S. Y. Liu, X. Q. Zhang, Y. Q. Chen, Chin. J. Catal., 2013, 34, 751-757.

[15] E. Aneggi, V. Cabbai, A. Trovarelli, D. Goi, Int. J. Photoenergy, 2012, 2012, 694721.

[16] Y. N. Zheng, K. Z. Li, H. Wang, X. Zhu, Y. G. Wei, M. Zheng, Y. H. Wang, Energy Fuels, 2016, 30, 638-647.

[17] D. Pakhare, J. Spivey, Chem. Soc. Rev., 2014, 43, 7813-7837.

[18] B. C. H. Steele, A. Heinzel, Nature, 2001, 414, 345-352.

[19] Q. Fu, H. Saltsburg, M. Flytzani-Stephanopoulos, Science, 2003, 301, 935-938.

[20] C. Wen, Y. Zhu, Y. Ye, S. Zhang, F. Cheng, Y. Liu, P. Wang, F. Tao, ACS Nano, 2012, 6, 9305-9313.

[21] X. X. Dai, W. Y. Jiang, W. L. Wang, X. L. Weng, Y. Shang, Y. H. Xue, Z. B. Wu, Chin. J. Catal., 2018, 39, 728-735.

[22] U. Menon, H. Poelman, V. Bliznuk, V. V. Galvita, D. Poelman, G. B. Marine, J. Catal., 2012, 295, 91-103.

[23] B. F. Jin, Y. C. Wei, Z. Zhao, J. Liu, Y. Z. Li, R. J. Li, A. J. Duan, G. Y. Jiang, Chin. J. Catal., 2017, 38, 1629-1641.

[24] D. K. Chen, D. D. He, J. C. Lu, L. P. Zhong, F. Liu, J. P. Liu, J. Yu, G. P. Wan, S. F. He, Y. M. Luo, Appl. Catal. B, 2017, 218, 249-259.

[25] H. D. Xu, Z. T. Fang, Y. Cao, S. Kong, Lin Tao, M. C. Gong, Y. Q. Chen, Chin. J. Catal., 2012, 33, 1927-1937.

[26] N. Laosiripojana, S. Assabumrungrat, Appl. Catal. B, 2011, 102, 267-275.

[27] M. Flytzani-Stephanopoulos, M. Sakbodin, Z. Wang, Science, 2006, 312, 1508-1510.

[28] D. D. He, G. P. Wan, H. S. Hao, D. K. Chen, J. C. Lu, L. Zhang, F. Liu, L. P. Zhong, S. F. He, Y. M. Luo, Chem. Eng. J., 2016, 289, 161-169.

[29] D. D. He, H. S. Hao, D. K. Chen, J. C. Lu, L. P. Zhong, R. Chen, F. Liu, G. P. Wan, S. F. He, Y. M. Luo, J. Environ. Chem. Eng., 2016, 4, 311-318.

[30] D. D. He, H. S. Hao, D. K. Chen, J. P. Liu, J. Yu, J. C. Lu, F. Liu, G. P. Wan, S. F. He, Y. M. Luo, Catal. Today, 2017, 281, 559-565.

[31] D. D. He, D. K. Chen, H. S. Hao, J. Yu, J. P. Liu, J. C. Lu, F. Liu, G. P. Wan, S. F. He, Y. M. Luo, Appl. Surf. Sci., 2016, 390, 959-967.

[32] R. Di Monte, J. Kaspar, J. Mater. Chem., 2005, 15, 633-648.

[33] L. Katta, P. Sudarsanam, G. Thrimurthulu, B. M. Reddye, Appl. Catal. B, 2010, 101, 101-108.

[34] S. Abdollahzadeh-Ghom, C. Zamani, T. Andreu, M. Epifani, J. R. Morante, Appl. Catal. B, 2011, 108-109, 32-38.

[35] M. Fabián, B. Antić, V. Girman, M. Vučinić-Vasić, A. Kremenović, S. Suzuki, H. Hahn, V. Šepelák, J. Solid State Chem., 2015, 230, 42-48.

[36] S. P. Wang, X. Y. Wang, J. Huang, S. M. Zhang, S. R. Wang, S. H. Wu, 


\section{Graphical Abstract}

Chin. J. Catal., 2018, 39: 1929-1941 doi: 10.1016/S1872-2067(18)63146-8

Relationship between oxygen species and activity/stability in heteroatom (Zr, Y)-doped cerium-based catalysts for catalytic decomposition of $\mathrm{CH}_{3} \mathrm{SH}$

Dingkai Chen, Dehua Zhang *, Dedong He, Jichang Lu, Liping Zhong, Caiyun Han, Yongming Luo*

Kunming University of Science and Technology
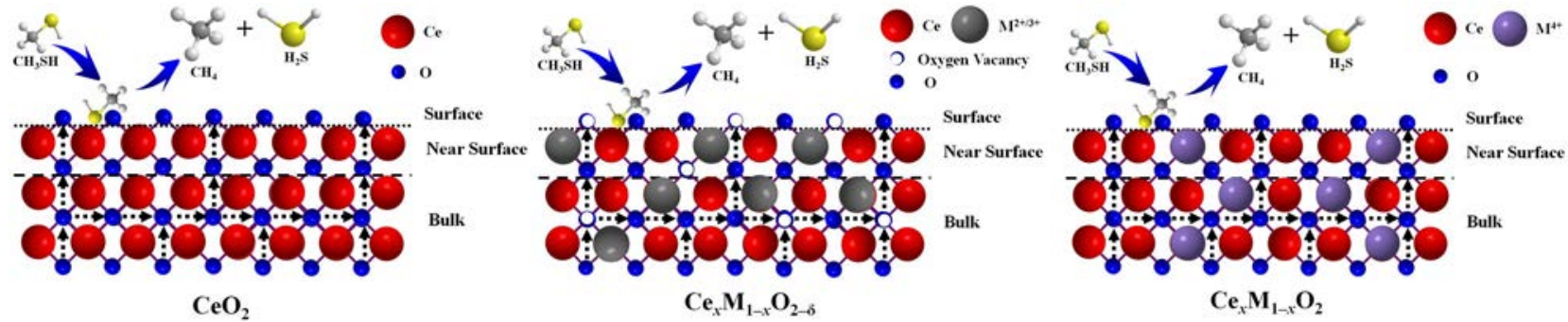

Surface lattice oxygen plays a key role in decomposing $\mathrm{CH}_{3} \mathrm{SH}$. Oxygen vacancies promote bulk lattice oxygen migration. The valence difference between the doped ions affects the catalytic behavior.

Catal. Commun., 2007, 8, 231-236.

[37] I. Dobrosz-Gómez, I. Kocemba, J. M. Rynkowski, Appl. Catal. B, 2008, 83, 240-255.

[38] Y. M. Luo, Z. Y. Hou, J. Gao, D. Jin, X. Zheng, Mater. Sci. Eng. B, 2007, $140,123-127$.

[39] X. L. Sang, L. Y. Zhang, H. Wang, D. D. He, L. Deng, S. Huang, J. Wang, Y. M. Luo, Powder Technol., 2014, 253, 590-595.

[40] D. Yang, L. Wang, Y. Z. Sun, K. Zhou, J. Phys. Chem. C, 2010, 114, 8926-8932.

[41] D. Harshini, D. H. Lee, J. Jeong, Y. M. Kima, S. W. Nama, H. C. Ham, J. H. Han, T. H. Lim, C. W. Yoon, Appl. Catal. B, 2014, 148-149, 415-423.

[42] D. Jampaiah, K. M. Tur, S. J. Ippolito, Y. M. Sabri, J. Tardio, S. K. Bhargava, B. M. Reddy, RSC Adv., 2013, 3, 12963-12974.

[43] W. Lee, S. Y. Chen, Y. S. Chen, C. L. Dong, H. J. Lin, C. T. Chen, A. Gloter, J. Phys. Chem. C, 2014, 118, 26359.

[44] H. P. Zhang, H. C. Liu, J. Energy Chem., 2013, 22, 98-106.

[45] A. Nakajima, A. Yoshihara, M. Ishigame, Phys. Rev. B, 1994, 50, 13297-13307.

[46] T. Taniguchi, T. Watanabe, N. Sugiyama, A. K. Subramani, H. Wagata, N. Matsushita, M. Yoshimura, J. Phys. Chem. C, 2009, 113, 19789-19793.
[47] J. Li, Y. X. Han, Y. H. Zhu, R. X. Zhou, Appl. Catal. B, 2011, 108-109, 72-80.

[48] A. Galtayries, R. Sporken, J. Riga, G. Blanchard, R. Caudano, J. Electron Spectrosc., 1998, 88, 951-956.

[49] A. E. Nelsona, K. H. Schulz, Appl. Surf. Sci., 2003, 210, 206-221.

[50] Z. Wang, Z. P. Qu, X. Quan, Z. Li, H. Wang, R. Fan, Appl. Catal. B, 2013, 134-135, 153-166.

[51] J. Hierso, O. Sel, A. Ringuede, C. Laberty-Robert, L. Bianchi, D. Grosso, C. Sanchez, Chem. Mater., 2009, 21, 2184-2192.

[52] Q. Ye, R. P. Wang, B. Q. Xu, Acta Phys. Chim. Sin., 2006, 22, 33-37.

[53] A. E. C. Palmqvist, M. Wirde, U. Gelius, M. Muhammed, Nanostruct. Mater., 1999, 11, 995-1007.

[54] C. T. Campbell, C. H. F. Peden, Science, 2005, 309, 713-714.

[55] Y. C. Wei, J. Liu, Z. Zhao, A. Duan, G. Jiang, J. Catal., 2012, 287, 13-29.

[56] I. Atribak, A. Buenolopez, A. Garciagarcia, J. Catal., 2008, 259, 123-132.

[57] Y. N. Zheng, K. Z. Li, H. Wang, Y. H. Wang, D. Tian, Y. G. Wei, X. Zhu, C. H. Zeng, Y. M. Luo, J. Catal., 2016, 344, 365-377.

[58] X. W. Liu, K. B. Zhou, L. Wang, B. Y. Wang, Y. D. Li, J. Am. Chem. Soc., 2009, 131, 3140-3141.

\section{杂原子 $(\mathrm{Zr}, \mathrm{Y})$ 掺杂的铈基催化剂中氧物种与其催化 $\mathrm{CH}_{3} \mathrm{SH}$ 分解的 活性/稳定性之间的关系}

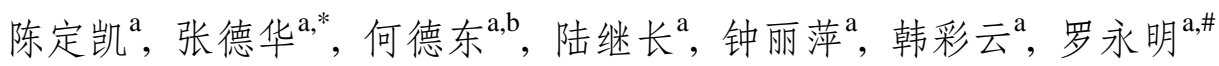

a昆明理工大学环境科学与工程学院, 云南昆明 650500

b昆明理工大学化学工程学院, 云南昆明650500

摘要: 铈基催化剂因其优异的储放氧能力被广泛地应用于多种催化反应. 铈基材料作为催化剂在 $\mathrm{CH}_{3} \mathrm{SH}$ (甲硫醇) 分解反 应中的应用也因其产物简单、易处理而受到越来越多的关注. 本课题组在前期研究中发现, 纳米二氧化铈在 $\mathrm{CH}_{3} \mathrm{SH}$ 催化 分解反应中表现出较高的催化活性, 然而催化剂却在很短时间内快速失活. 为进一步提高铈基氧化物的稳定性, 我们通过 引入稀土元素对氧化铈催化剂进行改性, 结果发现其稳定性明显提高; 同时催化剂稳定性与氧空位数量有关, 氧空位数量 
越多, 催化剂越稳定. 然而, 目前关于氧空位对催化 $\mathrm{CH}_{3} \mathrm{SH}$ 分解反应的具体作用, $\mathrm{CH}_{3} \mathrm{SH}$ 在铈基材料上的失活机理以及氧 物种与催化行为之间的相互关系尚不清楚. 因此, 有必要进一步研究氧空位对提高催化稳定性的贡献并揭示催化行为与 氧物种之间的相互关系.

本文通过微波辅助柠檬酸络合法制备一系列杂原子 $(\mathrm{Zr}, \mathrm{Y})$ 掺杂的铈基催化剂 $\mathrm{CeO}_{2}, \mathrm{Ce}_{1-x} \mathrm{Zr}_{x} \mathrm{O}_{2}, \mathrm{Ce}_{1-x} \mathrm{Y}_{x} \mathrm{O}_{2-\delta}(x=0.25$, $0.50,0.75,1.00)$, 通过考察锆、钇杂原子价态和离子半径对 $\mathrm{CH}_{3} \mathrm{SH}$ 催化分解活性和稳定性的影响来探索铈基催化剂中氧空 位的作用及氧物种与催化行为之间的关系. 其中, 氧物种与催化行为之间的关系可包括两类: (1) 表面晶格氧与催化活性 之间的关系; (2) 体相晶格氧迁移与催化稳定性之间的关系.

催化性能和表征结果表明, 铈基氧化物中表面晶格氧对 $\mathrm{CH}_{3} \mathrm{SH}$ 催化转化起着至关重要的作用. $\mathrm{Ce}_{0.75} \mathrm{Zr}_{0.25} \mathrm{O}_{2}$ 在 $\mathrm{CH}_{3} \mathrm{SH}$ 的催化分解中表现出更高的催化活性, 这是由于 $\mathrm{Ce}_{0.75} \mathrm{Zr}_{0.25} \mathrm{O}_{2}$ 有更多的表面晶格氧、活性氧物种及良好的氧化还原性能. $\mathrm{Ce}_{0.75} \mathrm{Y}_{0.25} \mathrm{O}_{2-\delta}$ 也表现出更好的催化稳定性, 这是由于催化剂中有更多的氧空位, 它们会促进体相晶格氧迁移到催化剂表面 以补充表面晶格氧. 此外, Ce 与杂原子之间化学价差极大地影响着表面晶格氧含量以及催化剂中体相氧的迁移率, 进而影 响铈基催化剂的活性和稳定性.

关键词: 铈基催化剂; 杂原子; 表面晶格氧; 甲硫醇分解; 体相氧迁移

收稿日期: 2018-05-29. 接受日期: 2018-07-23. 出版日期: 2018-12-05.

*通讯联系人. 电话/传真: (0871)65103845; 电子信箱: environcatalysis222@yahoo.com

\#通讯联系人. 电话/传真: (0871)65103845; 电子信箱: environcatalysis222@yahoo.com

基金来源：国家自然科学基金(21667016, 21267011, U1402233).

本文的电子版全文由Elsevier出版社在ScienceDirect上出版(http://www.sciencedirect.com/science/journal/18722067). 